In cooperation with the Miami Conservancy District

\title{
Arsenic in Ground Water in Selected Parts of Southwestern Ohio, 2002-03
}

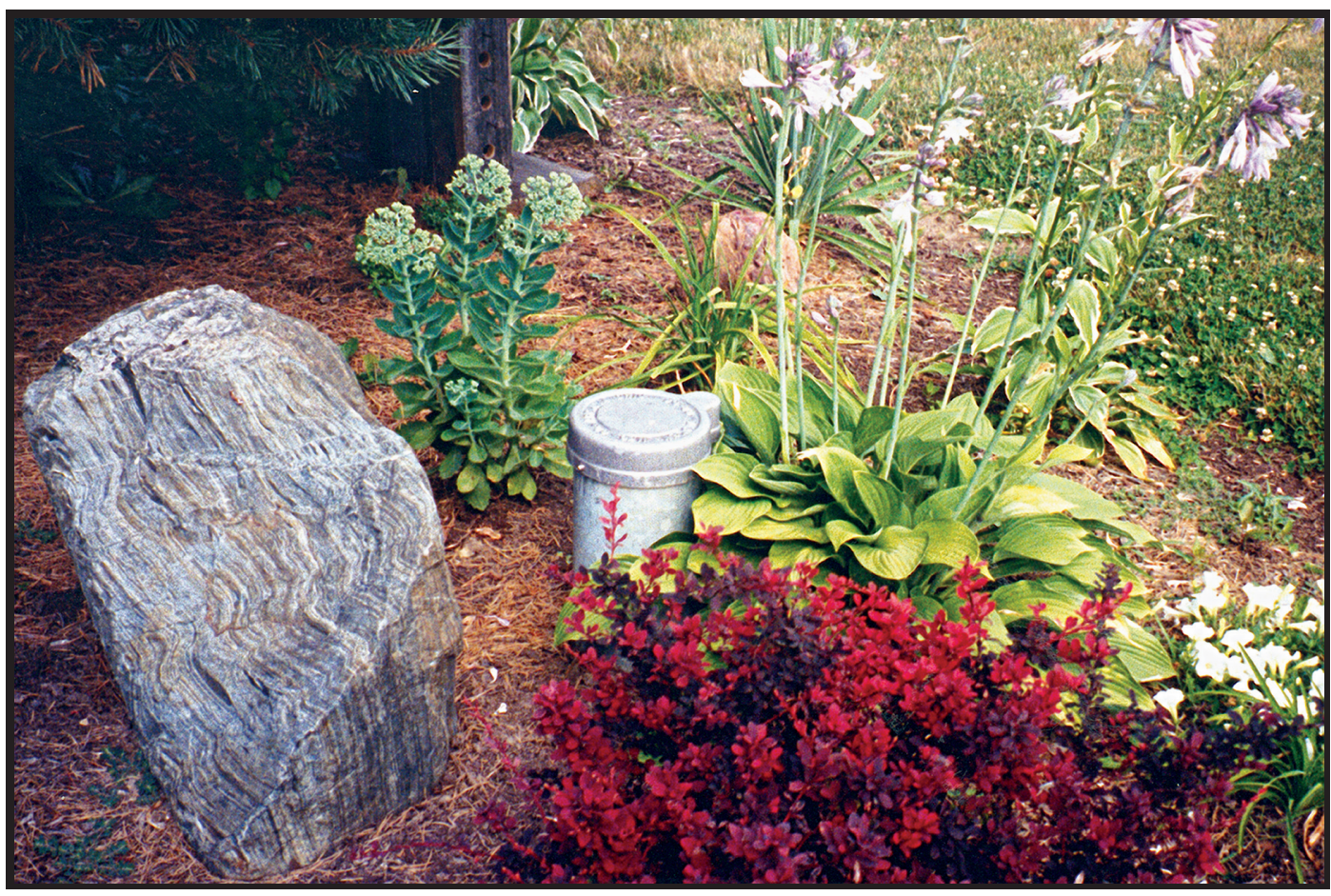

Scientific Investigations Report 2005-5138 
Cover Photo: One of the domestic wells sampled during this study (photo by Tom Schumann, U.S. Geological Survey). 


\section{Arsenic in Ground Water in Selected Parts of Southwestern Ohio, 2002-03}

By Mary Ann Thomas, Thomas L. Schumann, and Bruce A. Pletsch

In cooperation with the Miami Conservancy District

Scientific Investigations Report 2005-5138 


\section{U.S. Department of the Interior \\ Gale A. Norton, Secretary}

\section{U.S. Geological Survey \\ P. Patrick Leahy, Acting Director}

U.S. Geological Survey, Reston, Virginia: 2005

For sale by U.S. Geological Survey, Information Services
Box 25286, Denver Federal Center
Denver, CO 80225
For more information about the USGS and its products:
Telephone: 1-888-ASK-USGS
World Wide Web: http://www.usgs.gov/

Any use of trade, product, or firm names in this publication is for descriptive purposes only and does not imply endorsement by the U.S. Government.

Although this report is in the public domain, permission must be secured from the individual copyright owners to reproduce any copyrighted materials contained within this report.

Suggested citiation:

Thomas, M.A., Schumann, T.L., Pletsch, B.A., 2005. Arsenic in ground water in selected parts of southwestern Ohio, 2002-03: U.S. Geological Survey Scientific Investigations Report 2005-5138, 30 p. 


\section{Contents}

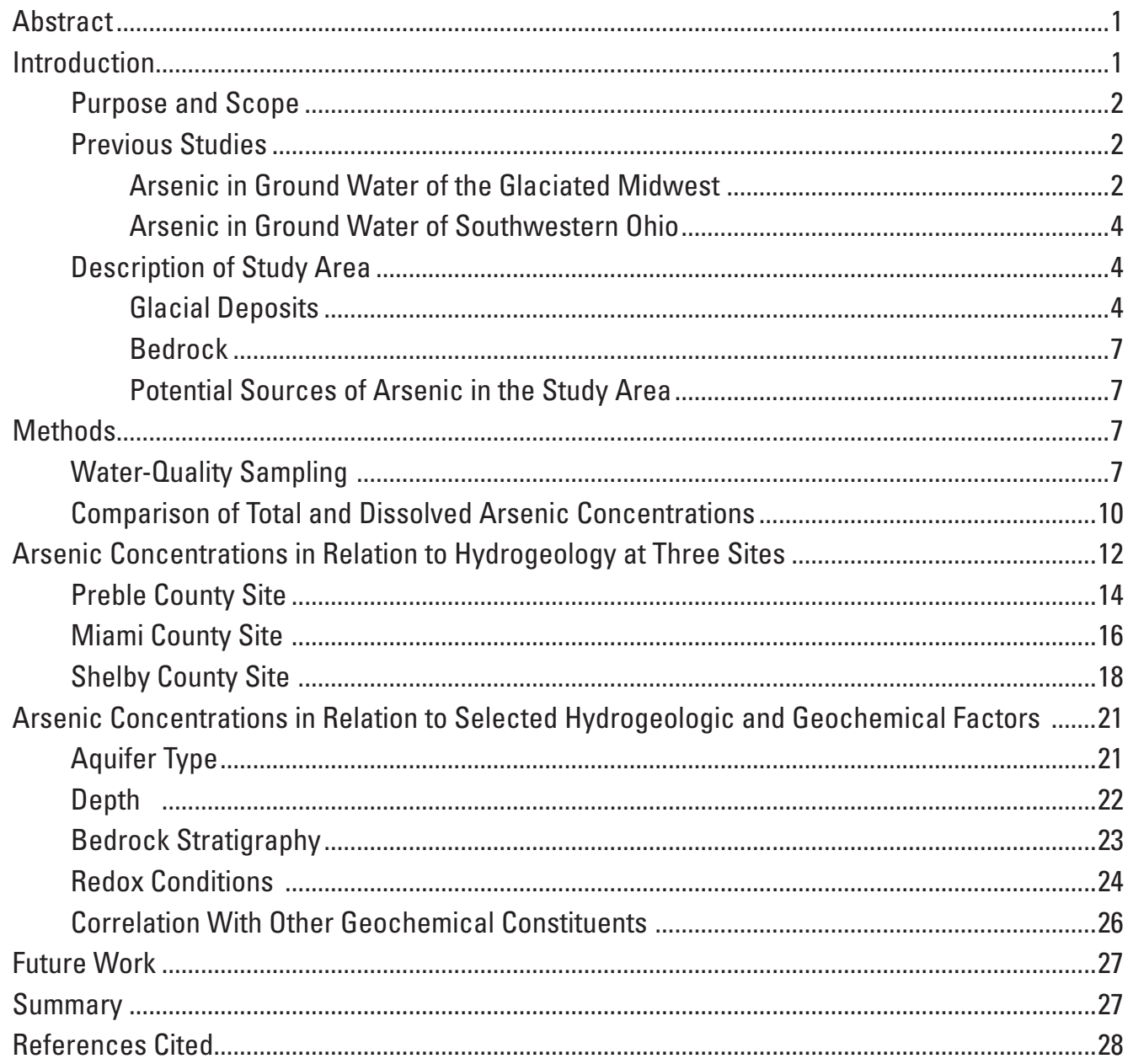

\section{Figures}

1-5. Maps showing-

1. Location of domestic wells sampled during 2002-2003 ....................................

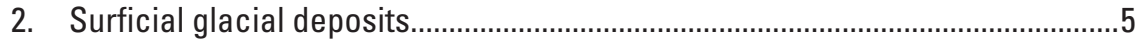

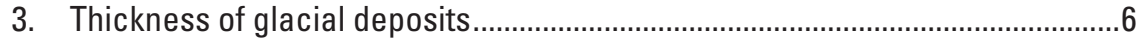

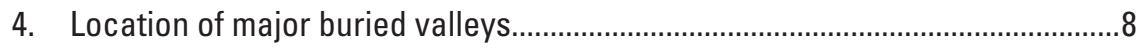

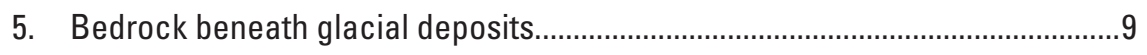

6. Graph showing determinations of total and dissolved concentrations of arsenic in glacial deposits and carbonate bedrock...................................................11

7. Map showing arsenic concentrations in selected domestic wells ................................13

8-10. Diagrams showing-

8. Arsenic concentrations in selected domestic wells in northern Preble County 
9. Arsenic concentrations in selected domestic wells in northwestern Miami County....

10. Arsenic concentrations in selected domestic wells in southern Shelby County

11-15. Graphs showing-

11. Arsenic concentrations in three aquifer types.

12. Relation between arsenic concentrations and well depth for all samples and depth to the top of the open interval for three aquifer types.

13. Arsenic concentrations in relation to the stratigraphic unit(s) included in the open interval of the well.

14. Relation between arsenic and iron concentrations in ground water. 24

15. Relations between arsenic concentrations, estimated redox conditions, and depth to the top of the open interval for three aquifer types

\section{Tables}

1. Generalized geologic column, southwestern Ohio ......................................................10

2. Chemical constituents with which arsenic is correlated in southwestern Ohio, based on results of Spearman's rho test 


\section{Conversion Factors and Datum}

\begin{tabular}{lcl}
\hline Multiply & By & To obtain \\
inch (in.) & 25.4 & millimeter $(\mathrm{mm})$ \\
foot (ft) & 0.3048 & meter $(\mathrm{m})$ \\
mile (mi) & 1.609 & kilometer $(\mathrm{km})$ \\
gallon per minute $(\mathrm{gal} / \mathrm{min})$ & 0.06309 & liter per second $(\mathrm{L} / \mathrm{s})$ \\
\hline
\end{tabular}

Vertical coordinate information is referenced to the North American Vertical Datum of 1988 (NAVD88).

Abbreviated water-quality units used in this report: Chemical concentrations and water temperature are given in metric units. Chemical concentration in water is given in milligrams per liter (mg/L), micrograms per liter $(\mu \mathrm{g} / \mathrm{L})$, or millimoles per liter $(\mathrm{mmol} / \mathrm{L})$. Milligrams per liter is a unit expressisng the concentration of chemical constituents in solution as weight (milligrams) of solute per unit volume (liter) of waer. One thousand micrograms per liter is equivalent to 1 milligram per liter. For concentrations less than $7,000 \mathrm{mg} / \mathrm{L}$, the numerical value is approximately the same as for concentrations in parts per million. 


\title{
Arsenic in Ground Water in Selected Parts of Southwestern Ohio, 2002-03
}

\author{
By Mary Ann Thomas, Thomas L. Schumann, and Bruce A. Pletsch'
}

\section{Abstract}

Arsenic concentrations were measured in 57 domestic wells in Preble, Miami, and Shelby Counties, in southwestern Ohio. The median arsenic concentration was $7.1 \mu \mathrm{g} / \mathrm{L}$ (micrograms per liter), and the maximum was $67.6 \mu \mathrm{g} / \mathrm{L}$. Thirtyseven percent of samples had arsenic concentrations greater than the U.S. Environmental Protection Agency drinkingwater standard of $10 \mu \mathrm{g} / \mathrm{L}$.

Elevated arsenic concentrations $(>10 \mu \mathrm{g} / \mathrm{L})$ were detected over the entire range of depths sampled (42 to $221 \mathrm{feet}$ ) and in each of three aquifer types-Silurian carbonate bedrock, glacial buried-valley deposits, and glacial till with interbedded sand and gravel.

One factor common in all samples with elevated arsenic concentrations was that iron concentrations were greater than $1,000 \mu \mathrm{g} / \mathrm{L}$. The observed correlations of arsenic with iron and alkalinity are consistent with the hypothesis that arsenic was released from iron oxides under reducing conditions (by reductive dissolution or reductive desorption).

Comparisons among the three aquifer types revealed some differences in arsenic occurrence. For buried-valley deposits, the median arsenic concentration was $4.6 \mu \mathrm{g} / \mathrm{L}$, and the maximum was $67.6 \mu \mathrm{g} / \mathrm{L}$. There was no correlation between arsenic concentrations and depth; the highest concentrations were at intermediate depths (about 100 feet). Half of the buried-valley samples were estimated to be methanic. Most of the samples with elevated arsenic concentrations also had elevated concentrations of dissolved organic carbon and ammonia.

For carbonate bedrock, the median arsenic concentration was $8.0 \mu \mathrm{g} / \mathrm{L}$, and the maximum was $30.7 \mu \mathrm{g} / \mathrm{L}$. Arsenic concentrations increased with depth. Elevated arsenic concentrations were detected in iron- or sulfate-reducing samples. Arsenic was significantly correled with molybdenum, strontium, fluoride, and silica, which are components of naturally ocurring minerals.

For glacial till with interbedded sand and gravel, half of the samples had elevated arsenic concentrations. The median was $11.4 \mu \mathrm{g} / \mathrm{L}$, and the maximum was $27.6 \mu \mathrm{g} / \mathrm{L}$. At shallow

\footnotetext{
${ }^{1}$ Miami Conservancy District.
}

depths ( $<100$ feet), this aquifer type had higher arsenic and iron concentrations than carbonate bedrock.

It is not known whether these observed differences among aquifer types are related to variations in (1) arsenic content of the aquifer material, (2) organic carbon content of the aquifer material, (3) mechanisms of arsenic mobilization (or uptake), or (4) rates of arsenic mobilization (or uptake). A followup study that includes solid-phase analyses and geochemical modeling was begun in 2004 in northwestern Preble County.

\section{Introduction}

Arsenic in drinking water has been linked to multiple health problems, including bladder, lung, and skin cancers; cardiovascular disease; diabetes; and neurological dysfunction (National Research Council, 1999). In recognition of the health risks associated with arsenic, the U.S. Environmental Protection Agency (USEPA) decreased the Maximum Contaminant Level (MCL) for arsenic from 50 to $10 \mu \mathrm{g} / \mathrm{L}$ on October 31, 2001 (U.S. Environmental Protection Agency, 2001). The new MCL will be enforceable for public water systems nationwide in 2006.

In southwestern Ohio, there is no clear pattern to the distribution of arsenic in ground water. Elevated arsenic concentrations ( $>10 \mu \mathrm{g} / \mathrm{L})$ have been reported in each of the major sources of ground water (glacial deposits and carbonate bedrock), at a range of depths (18 to $302 \mathrm{ft}$ ), and in a variety of well types (monitor, domestic, and public-supply wells). Moreover, ground-water samples from the same geographic area can have very different concentrations. It is not clear which combination(s) of hydrogeologic and geochemical factors are responsible for the sporadic elevated arsenic concentrations found in ground water. In light of the practical concerns resulting from the unpredictability of arsenic occurrence in southwestern Ohio ground water, the U.S. Geological Survey (USGS), in cooperation with the Miami Conservancy District (MCD), began a study in 2002 to relate arsenic concentrations to physical and chemical characteristics of the area aquifers. The ultimate goal, which extends beyond the scope of the current study, is to understand arsenic 
occurrence well enough to avoid drilling water-supply wells in parts of the ground-water system with highest risk of arsenic contamination. If avoidance is not possible, high-risk areas can be targeted for increased monitoring. Domestic well owners are especially vulnerable because most home water-treatment systems do not remove arsenic from drinking water (Petty, 2000a).

There are several reasons that source(s) and cause(s) of elevated arsenic concentrations in ground water are difficult to interpret: (1) Arsenic can result from human activity and from natural sources. Moreover, arsenic from natural sources can be released by human activities that alter physical and chemical conditions in the subsurface. (2) Minerals with which arsenic is associated-pyrite and iron oxides - are ubiquitous components of sedimentary bedrock and glacial deposits. (3) Arsenic can be mobilized in waters that are oxygen rich (oxic) or oxygen depleted (reducing). (4) Arsenic concentrations in the aquifer rock or sediment do not always correlate with arsenic concentrations in ground water (U.S. Geological Survey, 1999; Warner, 2001; Berg and others, 2001; Kirk and others, 2004).

\section{Purpose and Scope}

This report summarizes the findings of a cooperative USGS-MCD water-quality study in selected parts of southwestern Ohio. The goals of the study were to increase understanding of arsenic occurrence by (1) documenting its distribution relative to aquifer type and depth, and (2) identifying the hydrogeologic and geochemical factors related to elevated arsenic concentrations.

During 2002 and 2003, ground-water samples were collected from 57 domestic wells at sites in Preble, Miami, and Shelby Counties (fig. 1). Samples were analyzed for inorganic constituents (major ions, trace elements, and nutrients) and dissolved organic carbon. Geologic sections were used to illustrate the relation between arsenic concentrations, aquifer type, and depth. Graphical analysis, spatial relations, and nonparametric statistical analyses were used to identify relations between arsenic concentrations and possible explanatory factors.

\section{Previous Studies}

In ground water, arsenic is commonly present in two oxidation states. Arsenate $\left(\mathrm{H}_{\mathrm{n}} \mathrm{AsO}_{4}{ }^{\mathrm{n}-3}\right)$ has an oxidation state of +5 and is the predominant form of arsenic in oxic waters. Arsenite $\left(\mathrm{H}_{\mathrm{n}} \mathrm{AsO}_{3}{ }^{\mathrm{n}-3}\right)$ has an oxidation state of +3 and is the predominant form in reducing waters. Of the two forms, arsenite is the more toxic and the more mobile in solution.

Arsenic is associated with multiple naturally occurring compounds. Arsenic is a component of sulfide minerals; it substitutes into the crystalline lattice of silicates; and it sorbs to iron/manganese oxyhydroxides, clays, and organic matter. Presumably, arsenic can be mobilized under conditions in which these materials become unstable (Welch and others, 1988).

In addition to natural sources, arsenic has anthropogenic sources. Arsenic compounds are (or) were used in wood preservatives, swine and poultry feed, glass production, and in agricultural applications (Welch and others, 2000). Arsenic is detected in ground water beneath waste-disposal sites, but the source is not always anthropogenic; naturally occurring arsenic in the aquifer matrix can be released to ground water as a result of reducing conditions caused by a contaminant plume. Anthropogenic sources of arsenic have been linked to elevated arsenic concentrations in soil (Welch and others, 2000; Ryker, 2003), but most studies of elevated arsenic in ground water have concluded that the source of arsenic is natural rather than anthropogenic.

\section{Arsenic in Ground Water of the Glaciated Midwest}

One of the frequently cited sources of elevated arsenic concentrations in midwestern ground water is pyrite or other sulfide minerals. Arsenic-bearing sulfides were deposited in Paleozoic bedrock by large-scale migrations of ore-bearing fluids during late stages of the Ouachita and Appalachian orogenies (Goldhaber and others, 2003). Pyrite is unstable under oxic conditions. Pyrite is oxidized by oxygen in a bacterially mediated multistep process. It can also be oxidized by ferric iron or nitrate (Welch and others, 2000; Appelo and Postma, 1999).

Schreiber and others (2003) investigated arsenic concentrations in ground water in eastern Wisconsin, where wells produce from a Paleozoic sandstone aquifer that contains zones of arsenic-bearing sulfides. They proposed that arsenic concentrations greater than $1,000 \mu \mathrm{g} / \mathrm{L}$ were related to oxidation of the sulfides by oxygen entering well boreholes. Pyrite oxidiation was also one of the suggested causes of elevated arsenic concentrations in Paleozoic bedrock and glacial deposits of southeastern Michigan (Kolker and others, 2003).

A second commonly cited source of arsenic in midwestern ground water is iron or manganese oxyhydroxides. (For brevity, the term "iron oxides" will be used hereafter as shorthand for "iron or manganese oxyhydroxides.") Arsenic is associated with iron oxides in two ways: (1) It can coprecipitate with iron oxides and become incorporated into the mineral structure. Coprecipitated arsenic will be mobilized by reductive dissolution of the iron oxides. The reductant can be naturally occurring organic carbon, such as peat (McCarthur and others, 2001), sulfide minerals (Appelo and Postma, 1999), or synthetic organic chemicals (Welch and others, 2000). (2) Arsenic can also be sorbed onto the surface of iron oxides. Mobilization of arsenic can occur by reduction of arsenate by microbes (Zobrist, 2000), by desorption related to an increase in $\mathrm{pH}$ (Schlottman, 2001), or by desorption due to competing oxyanions such as phosphate (Welch and others, 2000). 


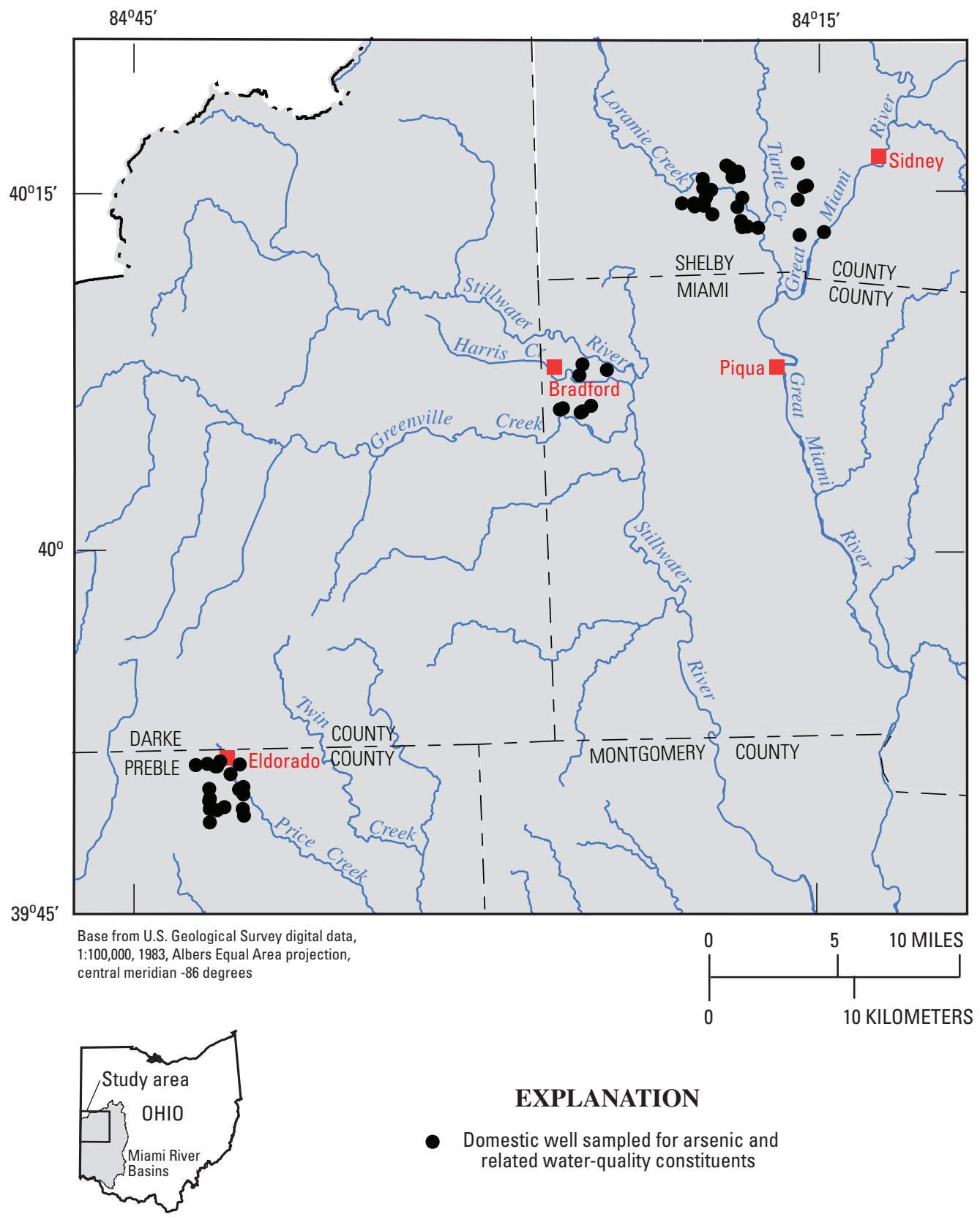

Figure 1. Location of domestic wells sampled during 2002-03, southwestern Ohio. 
Sorbed arsenic will also be released during reductive dissolution of iron oxides.

Matisoff and others (1982) investigated elevated arsenic concentrations in an area of northeastern Ohio where a buried valley dissects a sandstone aquifer overlain by till. They concluded that arsenic was released from iron oxides under reducing conditions. One possible reductant could have been methane gas leaking from deep underground storage. Another explanation that may have wider applicability to the glaciated Midwest is that iron oxides, which were initially deposited in a subaerial environment, had become unstable in a reducing environment created after a layer of surficial till restricted recharge to the aquifer.

Korte (1991) investigated elevated arsenic concentrations in ground water at sites in Missouri and Ohio and reviewed selected arsenic studies in other parts of the Midwest. He concluded that arsenic is released from iron oxides in response to a change from oxic to reducing conditions caused by sediment deposition. In addition, he proposed that the sporadic nature of arsenic detections may result because of local variations in redox conditions and that high arsenic concentrations were more likely to occur in low-yield wells in areas with relatively high amounts of clay.

Breit and others (2001) discussed cycling of arsenic between sulfides and iron oxides (and weathered biotite) in response to changes in geochemical environments caused by fluctuations of sea level, cycles of erosion and burial, and land use. Their study site was the Bengal Delta in eastern Bangladesh; however, the conclusions may be applicable to the Midwest, which was subjected to multiple cycles of glaciation during Pleistocene and major shifts of geochemical environments during deposition and erosion of Paleozoic bedrock.

\section{Arsenic in Ground Water of Southwestern Ohio}

In southwestern Ohio, elevated arsenic concentrations have been reported in carbonate bedrock by Bendula (1996), Dumouchelle (1998), the Ohio Environmental Protection Agency (2000 and 2002), and the Miami Conservancy District (2001). An investigation of arsenic in carbonate bedrock of northwestern Montgomery County showed that four of six domestic wells had arsenic concentrations greater than 10 $\mu \mathrm{g} / \mathrm{L}$ (Bendula, 1996). Dumouchelle (1998) sampled 25 domestic wells that produce from Silurian Lockport Dolomite in Darke, Miami, Montgomery, and Preble Counties, and 68 percent had arsenic concentrations greater than or equal to 10 $\mu \mathrm{g} / \mathrm{L}$.

Elevated arsenic concentrations have also been reported in glacial deposits of southwestern Ohio (Ohio Environmental Protection Agency, 2000 and 2002; Miami Conservancy District, 2001; Thomas, 2003; Rowe and others, 2004). A synthesis of arsenic data from 342 wells in glacial deposits of five midwestern states showed that the highest arsenic concentrations were detected in buried-valley deposits, especially those confined by a thick layer of till (Thomas, 2003).
The Ohio Environmental Protection Agency investigated arsenic in water from public-supply wells in Ohio (Slattery and others, 2000; Ohio Environmental Protection Agency, 2000, 2002). They documented that arsenic concentrations in treated and untreated water were not significantly different and that sand and gravel aquifers had higher arsenic concentrations than carbonate or sandstone aquifers. Elevated arsenic concentrations were most likely to occur in waters with high concentrations of iron $(>700 \mu \mathrm{g} / \mathrm{L})$ and low concentrations of nitrate. In addition, arsenic concentrations were inversely related to production rate (or size) of the public-supply system.

The Ohio Department of Health documented the occurrence of arsenic in domestic wells in parts of southeastern Ohio, and determined that the highest arsenic concentrations were generally detected in wells completed in upper Mississippian sandstone immediately underlying valley-fill deposits (Petty, 2000a, b).

\section{Description of Study Area}

The study area includes three sites in the northwestern part of the Great Miami River Basin — northern Preble County, western Miami County, and southern Shelby County (fig. 1). The area is part of the Till Plains section of the Central Lowlands Physiographic Province (Fenneman and Johnson, 1946). Topography is relatively flat; most of the relief is associated with river valleys or glacial moraines. The area lies north and west of Dayton, and land use is predominantly agricultural and rural residential.

Glacial deposits are at land surface and are underlain by Silurian carbonate bedrock. Domestic and public-supply wells produce water from glacial deposits and bedrock. In terms of regional ground-water flow and geochemistry, the glacial deposits and the underlying Silurian carbonate bedrock are considered to be a single regional aquifer system (Eberts and George, 2000).

\section{Glacial Deposits}

The three major types of glacial deposits in the study area are till, coarse-grained sediment, and fine-grained sediment (fig. 2). Coarse-grained sediment is predominantly sand and gravel deposited by glacial meltwaters. Fine-grained sediment is predominantly clay associated with former lakes. The most widespread deposit is till, a heterogeneous mixture of clay, silt, sand, and gravel that was deposited directly by the glacier as end moraines (broad, rolling hills) or ground moraine (relatively flat plains). Till is typically clay rich, but it often contains lenses or layers of sand and gravel of varied thickness and extent. The upper 15 to $35 \mathrm{ft}$ of clay-rich till is commonly fractured (Strobel, 1993).

Glacial deposits in the study area are typically 20 to $150 \mathrm{ft}$ thick, but they can be as much as $400 \mathrm{ft}$ thick in buried valleys (fig. 3). Some buried valleys were formed by a pre- 
glacial (Teays) river system, and others formed as a result of drainage disturbances during glaciation. In many parts of the study area, these ancestral valleys are not visible at land surface because they are buried under glacial deposits (predominantly till). The deepest parts of the buried valleys are illustrated in figure 4.

Within the glacial deposits, the major sources of ground water are (1) coarse-grained sediment in buried-valley deposits, and (2) till with interbedded sand and gravel lenses. Well yields depend on the thickness, extent, and degree of sorting of the sand and gravel deposits. Typical well yields are 3 to $25 \mathrm{gal} / \mathrm{min}$ in buried valleys and 3 to $10 \mathrm{gal} / \mathrm{min}$ in till with interbedded sand and gravel (Kostelnick, 1983; Schmidt, 1984; Walker, 1986). Wells in glacial deposits commonly have screened or open intervals of $5 \mathrm{ft}$ or less.

\section{Bedrock}

The study area is near the axis of the Cincinnati-Findlay Arch, and bedrock dips 5 to $10 \mathrm{ft} / \mathrm{mi}$ to the north-northwest (Norris and Fidler, 1973). Silurian carbonate bedrock underlies the glacial deposits in most of the study area, but Ordovician shale with minor amounts of limestone subcrops in some of the deeper buried valleys (figs. 4 and 5).

Carbonate bedrock is the predominant source of ground water in areas where the glacial deposits are thin or do not contain sufficient amounts of sand or gravel. Well yields can range from 5 to $100 \mathrm{gal} / \mathrm{min}$ (Kostelnick, 1983; Schmidt, 1984; Walker, 1986). Wells in carbonate bedrock produce water from open intervals that can vary in length from less than $5 \mathrm{ft}$ to more than $100 \mathrm{ft}$. Ordovician shale is used as a source of domestic supply in some areas of southwestern Ohio, but it is not a common source of drinking water in the study area. Well yields in that shale are typically less than 2 gal/min (Schmidt, 1984).

A generalized geologic column for southwestern Ohio is given in table 1. Upper Ordovician rocks consist of calcareous shale with interbedded fossiliferous limestone and minor dolomite. The Rochester Shale equivalent is very thin and not recognizable as a distinct unit in the study area (Schumacher, 1993).

The Lower Silurian sub-Lockport formation (local nomenclature; Schumacher, 1993) subcrops adjacent to buried valleys. The upper section consists of calcareous dolomite, argillaceous dolomite, and dolomite with shale partings. The lower section (18-46 ft) has a greater proportion of calcareous deposits; it is described as limestone, dolomitic limestone, calcareous dolomite, argillaceous dolomite, and dolomite (Schumacher, 1993).

The Lower Silurian Lockport Dolomite underlies most of the study area, except near buried valleys, where it has been eroded away. It is described as white to gray microcrystalline to coarsely crystalline dolomite with abundant vuggy porosity. It has rare shale partings and rare chert in its basal part (Schumacher, 1993).
The Upper Silurian Salina Formation is present only in the northeastern corner of the Shelby County site. It is described as gray to yellowish-gray dolomite with rare shale and chert. Anyhydrite (or gypsum?) beds and laminations are also present (Schumacher, 1993).

\section{Potential Sources of Arsenic in the Study Area}

Sulfides and iron oxides - the two most frequently cited sources of arsenic - are common in bedrock and glacial deposits of the study area. Sulfide minerals have been identified in each of the Silurian and Ordovician bedrock formations that subcrop in southwestern Ohio (Stout, 1941; Hopkins, 1954; Gerrard, 1959; Botoman, 1975; Botoman and Stieglitz, 1978; core descriptions on file at the Columbus, Ohio, offices of the Ohio Department of Natural Resources, Division of Geological Survey). Glacial deposits are composed of a large proportion of local bedrock, so sulfides in bedrock are expected to be incorporated into the glacial deposits.

Iron oxides also are present in bedrock and glacial deposits (Gerrard, 1959; Blackman, 1970; core descriptions on file at the Columbus, Ohio, offices of the Ohio Department of Natural Resources, Division of Geological Survey). Iron oxides form when iron-bearing minerals are attacked by water (Hem, 1985). Iron oxides are expected to be widespread near erosional unconformities (although iron oxides are not limited to erosional unconformities). In the study area, erosional unconformities occur (1) at the contact between Silurian bedrock and Pleistocene glacial deposits and (2) at erosional surfaces within glacial deposits.

\section{Methods}

Southwestern Ohio was selected for study because elevated arsenic concentrations had been detected in previous water-quality investigations (Bendula, 1996; Dumouchelle, 1998; Ohio Environmental Protection Agency, 2000; Miami Conservancy District, 2001; Thomas, 2003). This study focused on areas near three small public-supply wells that were found to produce water with elevated arsenic concentrations in previous MCD water-quality analyses. Within a 5-mi radius of each public-supply well, drillers' logs from domestic wells were examined to select wells for sampling. The goal was to select domestic wells that produce water from a variety of depths and hydrogeologic settings at each site.

\section{Water-Quality Sampling}

A total of 57 domestic wells were sampled; 29 were sampled during June and July 2002, and 28 additional wells were sampled during July and August 2003. Procedures for well purging, sample collection and preservation, and 


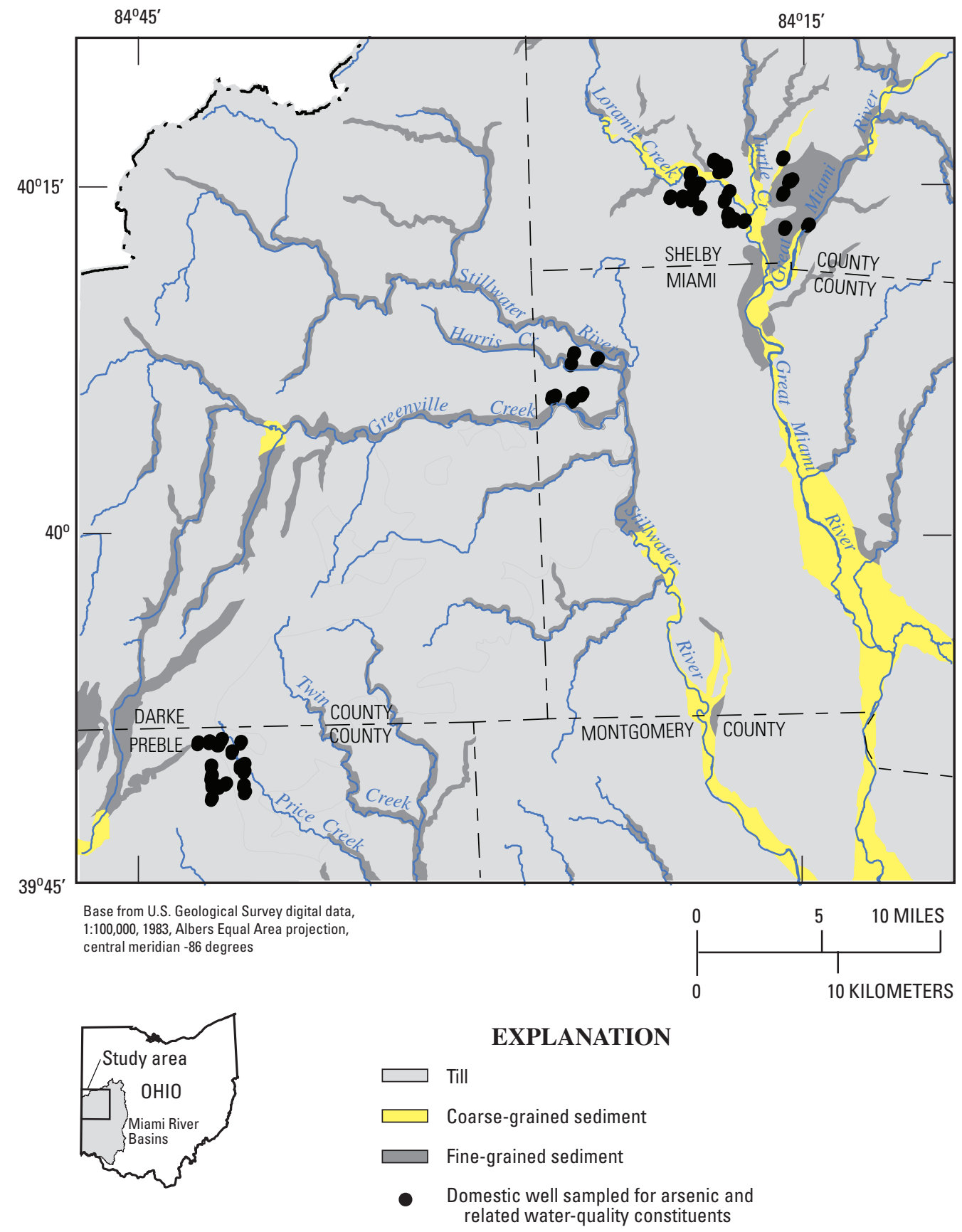

Figure 2. Surficial glacial deposits, southwestern Ohio (from Soller and Packard, 1998). 

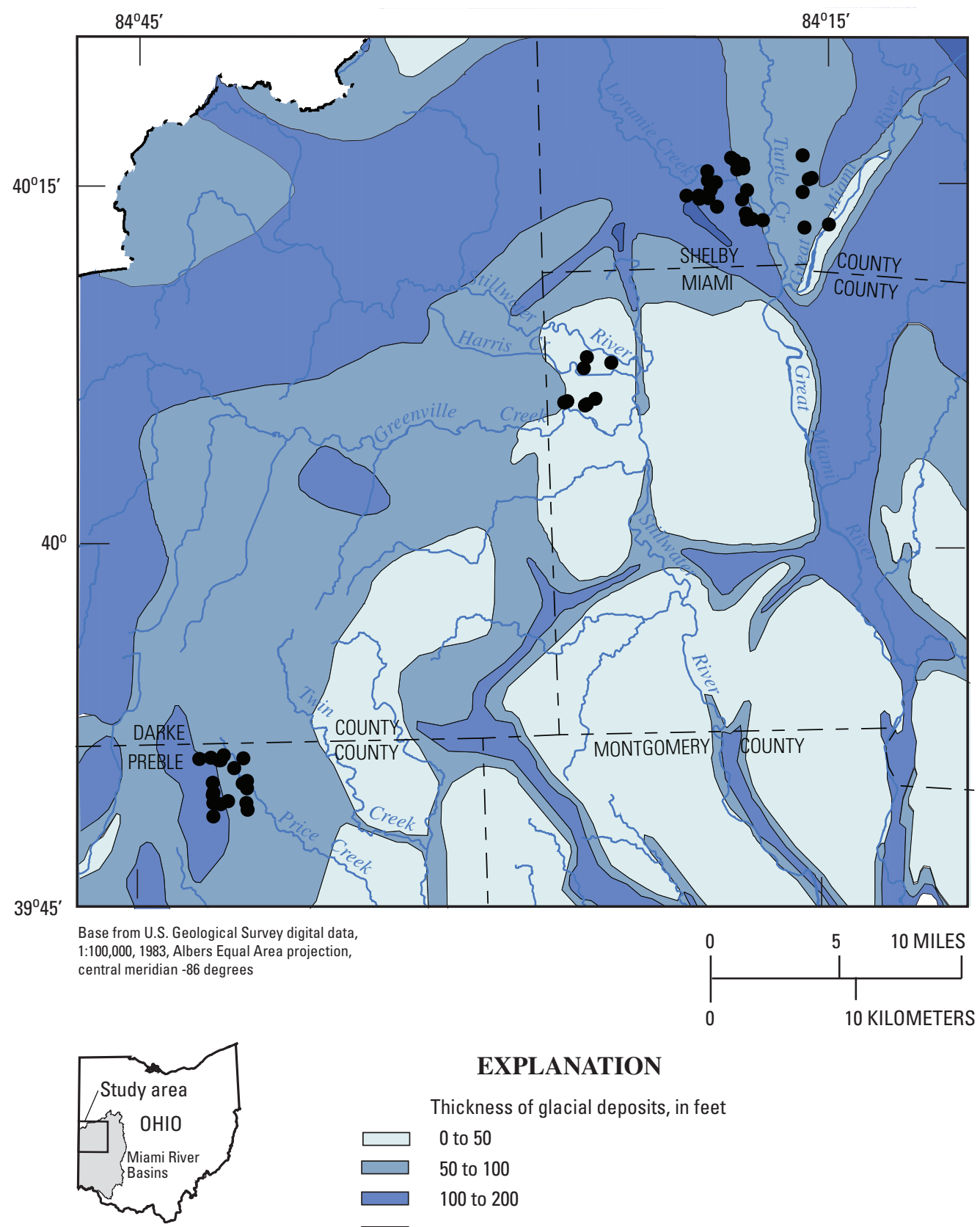

\section{EXPLANATION}

Thickness of glacial deposits, in feet

0 to 50

50 to 100

100 to 200

200 to 400

- Domestic well sampled for arsenic and related water-quality constituents

Figure 3. Thickness of glacial deposits, southwestern Ohio (from Soller and Packard, 1988). 

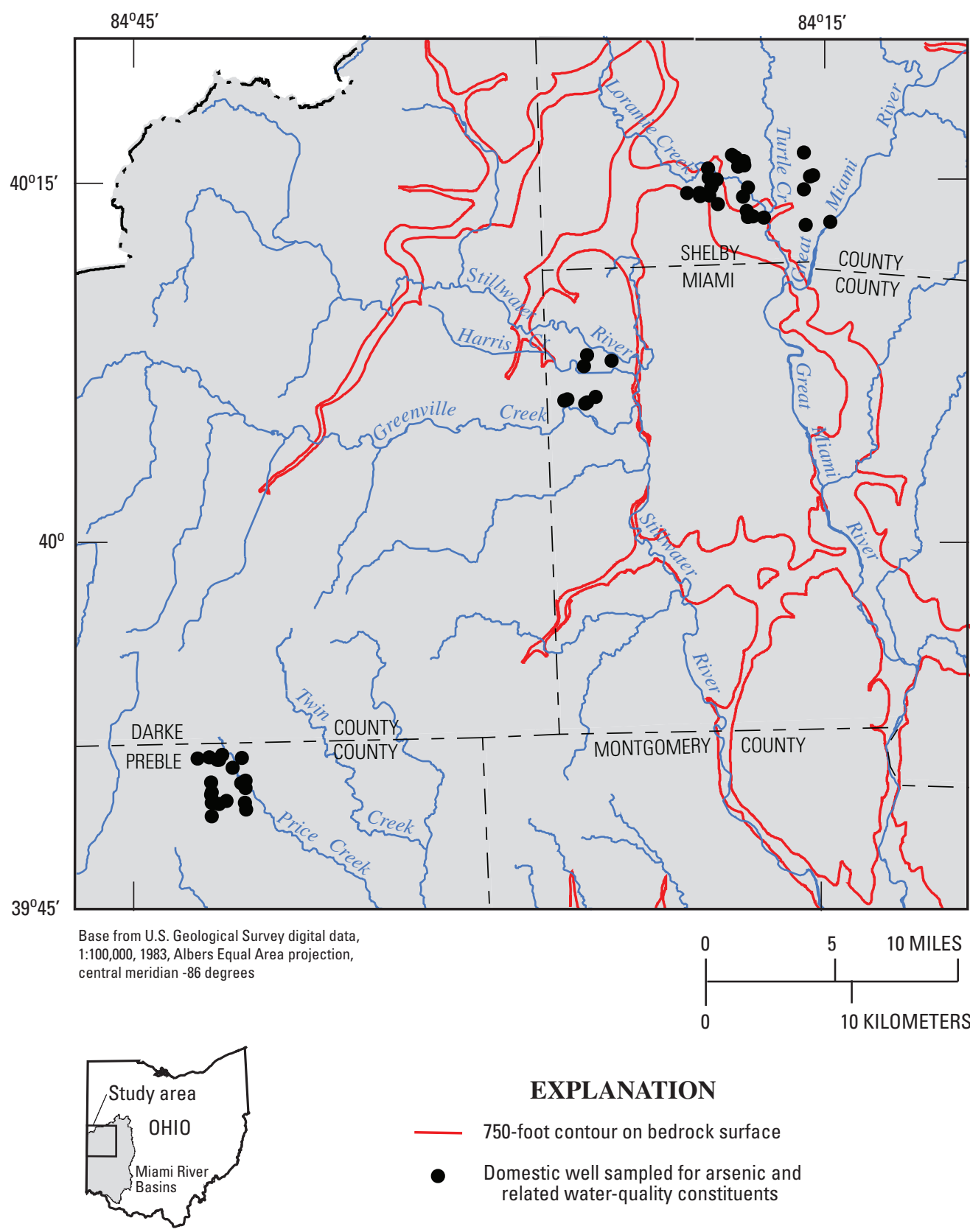

\section{EXPLANATION}

750-foot contour on bedrock surface

- Domestic well sampled for arsenic and related water-quality constituents

Figure 4. Location of major buried valleys, southwestern Ohio (from the Ohio Department of Natural Resources Division of Geological Survey, 2004). 


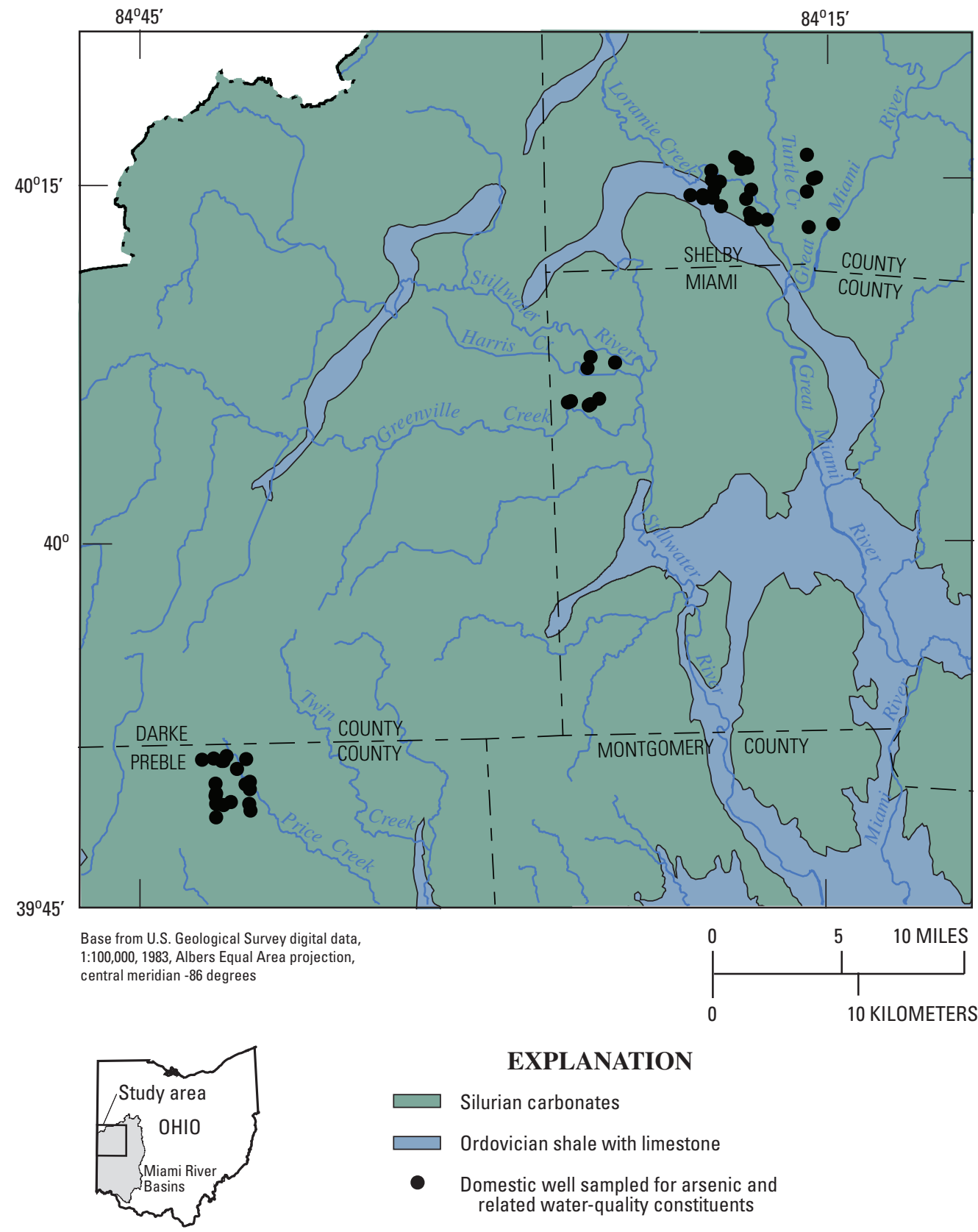

Figure 5. Bedrock beneath glacial deposits, southwestern Ohio (from Schruben and others, 1997). 
Table 1. Generalized geologic column, southwestern Ohio.

[Modified from Casey (1992), Schumacher (1993), and Eberts and George (2000); ^^^, unconformity]

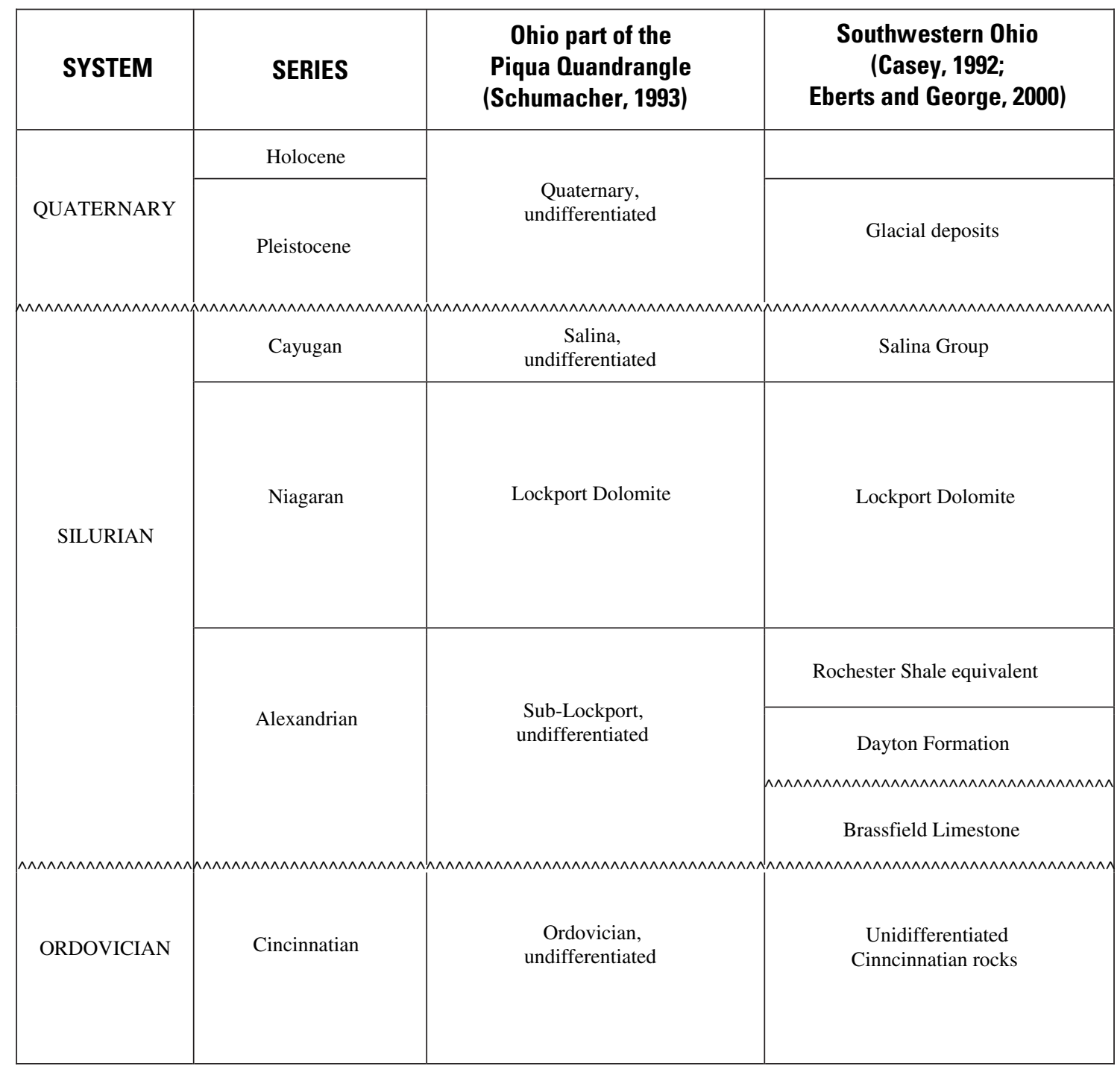

quality assurance were consistent with standard protocols of the USGS (Wilde and others, 1999). Samples were sent to the USGS National Water Quality Laboratory for analysis of major ions, trace elements, nutrients, and dissolved organic carbon (Fishman, 1993; Brenton and Arnette, 1993; Garbarino, 1999). Field determinations were made for $\mathrm{pH}$, dissolved oxygen, specific conductance, and temperature (using a multiparameter instrument and a flowthrough chamber), alkalinity (using electrometric titration), and turbidity (using a turbidimeter). For samples collected in 2003, field determinations of sulfide and ferrous iron were made using a spectrophotomer (Hach Company, 1993). The water-quality data are available in
USGS annual water-data reports for Ohio (Shindel and others, 2003, 2004).

Wells were purged before sampling; and, with one exception, samples were collected from spigots that bypassed water softeners. For one well (PR-222), the water sample was inadvertently collected after it had gone through a water softener. Cation concentrations from this sample were not included in water-quality analyses. However, the arsenic concentration was assumed to be unaffected by the water softener. This assumption was confirmed by analyzing an unsoftened sample from PR-222 in 2004. 


\section{Comparison of Total and Dissolved Arsenic Concentrations}

The USEPA MCL is based on total arsenic concentrations from unfiltered samples, whereas the USGS typically measures dissolved arsenic concentrations from filtered samples. In this study, both determinations were made to compare the two values. Total arsenic concentrations were determined on unfiltered samples by means of the graphite furnace atomic-absorption (GFAA) method with a reporting limit of $2 \mu \mathrm{g} / \mathrm{L}$. For dissolved arsenic determinations, samples were collected through $0.45-\mu \mathrm{m}$ capsule filters and analyzed by inductively coupled mass spectrometry (ICP/MS) with a reporting limit of $0.26 \mu \mathrm{g} / \mathrm{L}$. Comparisons were made only for the 43 samples with total arsenic concentrations greater than 2 $\mu \mathrm{g} / \mathrm{L}$, which is the highest common reporting limit for the two methods (fig. 6).

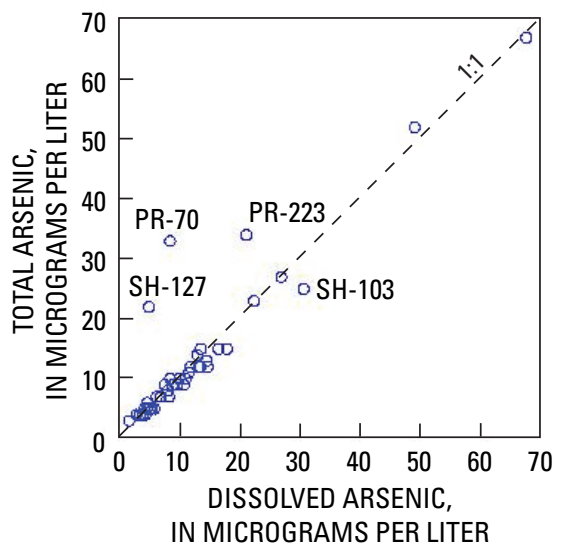

Figure 6. Determinations of total and dissolved concentrations of arsenic in glacial deposits and carbonate bedrock, southwestern Ohio.

Agreement was relatively good between the two values in each well. For the dataset as a whole, the two measurements were not significantly different $(\mathrm{p}=0.23)$ based on results of the Wilcoxon signed-ranks test at a 95-percent confidence level. Nevertheless, 4 of the 43 samples (9 percent) had total arsenic concentrations that are visibly different from dissolved concentrations on figure 6. Samples from two of the wells (PR-70 and PR-223) had elevated turbidity (80 and 17 NTU, respectively), and this is probably why arsenic concentrations were higher in unfiltered than in filtered samples. The other two samples (SH-127 and SH-103) did not have elevated turbidity (1.2 and $0.8 \mathrm{NTU}$ ). The samples were from wells less than 1,000 ft apart, and both wells produced from long open intervals (121 and $68 \mathrm{ft}$ ) in carbonate bedrock. It is possible that water in the wellbore was being contributed by multiple stratigraphic horizons with differing arsenic concentrations. The filtered sample was collected a few minutes before the unfiltered sample, and the two samples could have been contributed from different parts of the carbonate bedrock.

In the remainder of the report, "arsenic concentrations" will refer to concentrations of dissolved arsenic. An exception was made for the four samples with differing total and dissolved arsenic concentrations. For these samples, it was not clear which type of arsenic measurement to use during analysis of the dataset. In relation to human health, it made sense to use total concentrations because (1) that is the basis of the USEPA MCL and (2) homeowners do not typically drink water filtered at $0.045 \mu \mathrm{m}$. On the other hand, most geochemical studies use dissolved concentrations, so using total concentrations might seem like an attempt to overstate the problem. As a compromise, for the four samples with dissimilar values of total and dissolved arsenic (PR-70, PR-223, SH-127, and SH-103), an average of the total and dissolved concentrations was used for analysis. This compromise might not be ideal, but it was judged to be the best way to account for the observed variability without underestimating the arsenic concentrations of the water consumed by the owners of those four wells. 


\section{Arsenic Concentrations in Relation to Hydrogeology at Three Sites}

Ground-water samples were analyzed from the 57 selected domestic wells in southwestern Ohio. Thirty-seven percent of samples had elevated arsenic concentrations (greater than or equal to the MCL of $10 \mu \mathrm{g} / \mathrm{L}$ ). The median arsenic concentration was $7.1 \mu \mathrm{g} / \mathrm{L}$, and the maximum was $67.6 \mu \mathrm{g} / \mathrm{L}$.

Arsenic concentrations were plotted on geologic sections to illustrate how arsenic is distributed within the ground-water system at each site. The geologic sections were based on 1:24,000 maps of geologic structure and bedrock topography obtained from the Ohio Department of Natural Resources, Division of Geological Survey. In a few places, the data from the maps were slightly revised on the basis of additional information provided by drillers' logs from wells sampled for this study.

The 57 wells were distributed among three study sites in Preble, Miami, and Shelby Counties (fig. 7). The three sites are in the same general geologic setting—glacial deposits overlying Silurian carbonate bedrock. However, the sites differ somewhat in terms of hydrogeologic factors such as (1) thickness of glacial deposits, (2) areal extent and depth of buried valleys, (3) position within the regional ground-water-flow system, and (4) stratigraphic position of carbonate bedrock subcrops.

Elevated arsenic concentrations were detected in samples from at least one domestic well at each of the study sites. The maximum arsenic concentration $(67.6 \mu \mathrm{g} / \mathrm{L})$ was detected at the Preble County site. This site also had the highest percentage of samples exceeding the MCL (48 percent). Miami County had the lowest maximum concentration $(13.7 \mu \mathrm{g} / \mathrm{L})$ and the lowest percentage of samples exceeding the MCL (12 percent). 


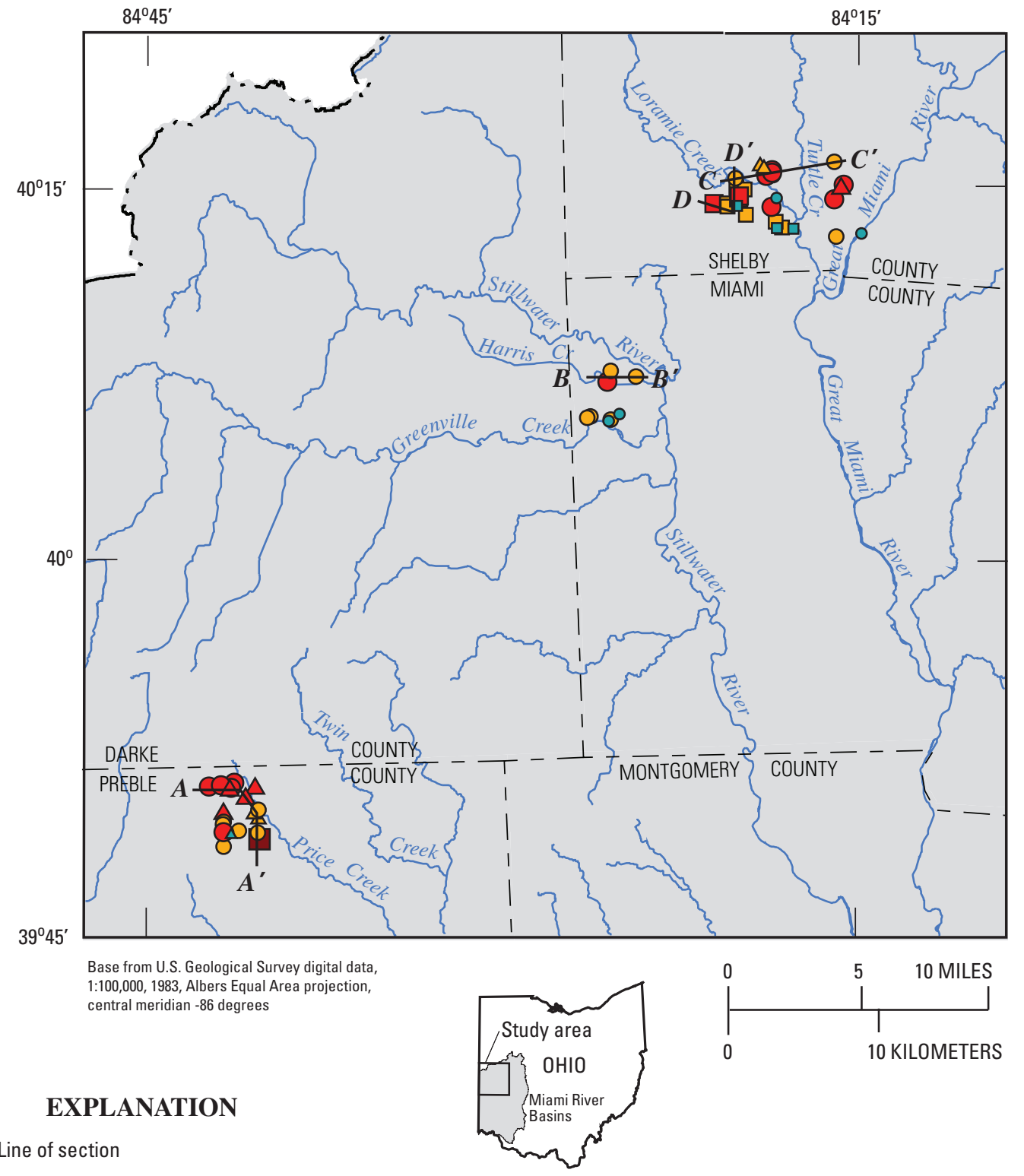

$\boldsymbol{A}-\boldsymbol{A}^{\prime}$ Line of section

Arsenic concentration, in micrograms per liter

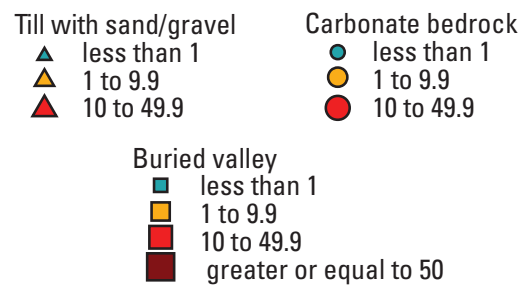

\begin{tabular}{|c|c|c|c|c|}
\hline \multirow{2}{*}{$\begin{array}{l}\text { Study } \\
\text { site }\end{array}$} & \multirow{2}{*}{$\begin{array}{l}\text { Wells } \\
\text { sampled }\end{array}$} & \multicolumn{2}{|c|}{$\begin{array}{l}\text { Arsenic concentration, } \\
\text { micrograms per liter }\end{array}$} & \multirow{2}{*}{$\begin{array}{c}\text { Percentage } \\
\text { of samples } \\
\text { exceeding } 10 \\
\text { micrograms } \\
\text { per liter }\end{array}$} \\
\hline & & Median & Maximum & \\
\hline Preble County & 21 & 9.8 & 67.6 & 48 \\
\hline Miami County & 8 & 7.7 & 13.7 & 12 \\
\hline Shelby County & 28 & 5.4 & 49.1 & 36 \\
\hline
\end{tabular}

Figure 7. Arsenic concentrations in selected domestic wells, southwestern Ohio. 


\section{Preble County Site}

This Preble County site is near the northwestern ground-water divide of the Great Miami River Basin. Land-surface elevations are 1,125 to $1,200 \mathrm{ft}$, and depth to water is 9 to $60 \mathrm{ft}$ below land surface. Maps of regional ground-water flow in the glacial deposits and carbonate bedrock indicate that this is an area of regional ground-water recharge (Eberts and George, 2000).

Glacial deposits are 35 to $120 \mathrm{ft}$ thick and are predominantly till with interbedded sand and gravel. A minor buried valley (about $110 \mathrm{ft}$ deep) extends into southeastern corner of the study area (Ohio Department of Natural Resources, Division of Geological Survey, 2004). Silurian carbonate bedrock is 30 to $200 \mathrm{ft}$ thick. The upper and middle parts of the Lockport Dolomite subcrop at the site (Ohio Department of Natural Resources, Division of Geological Survey, 2004).

This site was of interest because elevated concentrations of arsenic had been detected in samples from a 171-ft-deep public-supply well in carbonate bedrock. Between October 1999 and July 2003, seven samples from the public-supply well were analyzed for arsenic; the median concentration was $12 \mu \mathrm{g} / \mathrm{L}$, and the range was 11-13 $\mu \mathrm{g} / \mathrm{L}$ (Miami Conservancy District, 2004).

Within a 2.5-mi radius of the public-supply well, 21 domestic wells were sampled for arsenic and related water-quality constituents. The wells were chosen to represent a range of depths and aquifer types. Almost half of the wells (10 of 21) had arsenic concentrations greater than the MCL. The median arsenic concentration was $9.8 \mu \mathrm{g} / \mathrm{L}$, and the maximum was 67.6 $\mu \mathrm{g} / \mathrm{L}$.

Samples were from three types of aquifers-13 were from carbonate bedrock, 7 were from till with interbedded sand and gravel, and 1 was from buried-valley deposits. Elevated arsenic concentrations were detected in at least one well in each of the three aquifer types (fig. $8 \mathrm{~A})$. The wells were 42 to $161 \mathrm{ft}$ deep, and elevated arsenic concentrations were detected over almost the entire range of depths (fig. 8B).

A geologic section that extends from the northwestern to the southeastern corners of the site is shown in figure 8C. Relations among arsenic concentrations, well depth, and aquifer type are not simple or consistent. For example, similar arsenic concentrations were detected at different depths in the carbonate bedrock (compare PR-221 and PR-211), and different arsenic concentrations were detected at similar depths in till with interbedded sand and gravel (compare PR-223, PR-220 and PR-206). The maximum arsenic concentration $(67.6 \mu \mathrm{g} / \mathrm{L})$ was detected in a minor buried valley (PR-222). 
$\boldsymbol{A}$

\begin{tabular}{|c|c|c|c|c|}
\hline \multirow{2}{*}{$\begin{array}{l}\text { Aquifer } \\
\text { type }\end{array}$} & \multirow{2}{*}{$\begin{array}{l}\text { Number } \\
\text { of } \\
\text { samples }\end{array}$} & \multicolumn{2}{|c|}{$\begin{array}{l}\text { Arsenic concentration, } \\
\text { micrograms per liter }\end{array}$} & \multirow{2}{*}{$\begin{array}{c}\text { Percentage } \\
\text { of samples } \\
\text { exceeding } 10 \\
\text { micrograms } \\
\text { per liter }\end{array}$} \\
\hline & & Median & Maximum & \\
\hline Carbonate & 13 & 7.7 & 20.8 & 38 \\
\hline $\begin{array}{r}\text { Till with sand } \\
\text { and gravel }\end{array}$ & 7 & 13.1 & 27.6 & 57 \\
\hline Buried valley & ${ }^{\mathrm{a}} 1$ & -- & 67.6 & -- \\
\hline
\end{tabular}

${ }^{\mathrm{a}}$ Insufficient data to calculate summary statistics.
$\boldsymbol{B}$

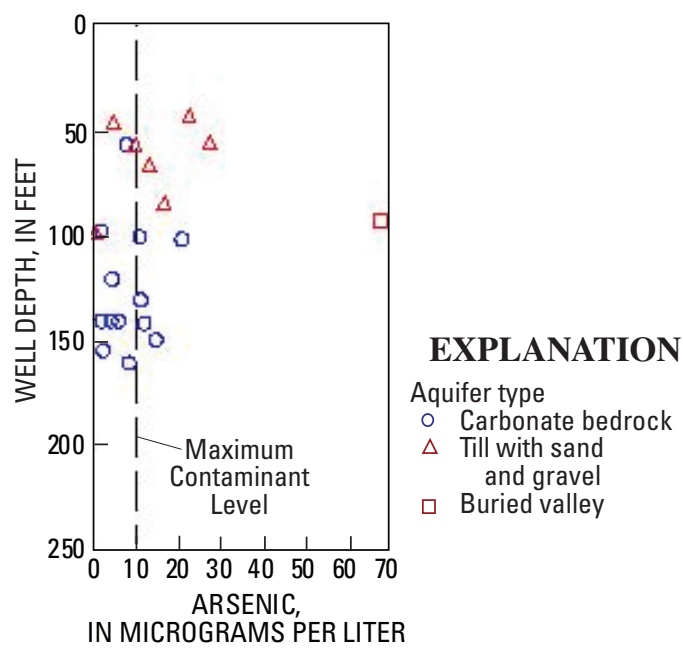

C

$\boldsymbol{A}$

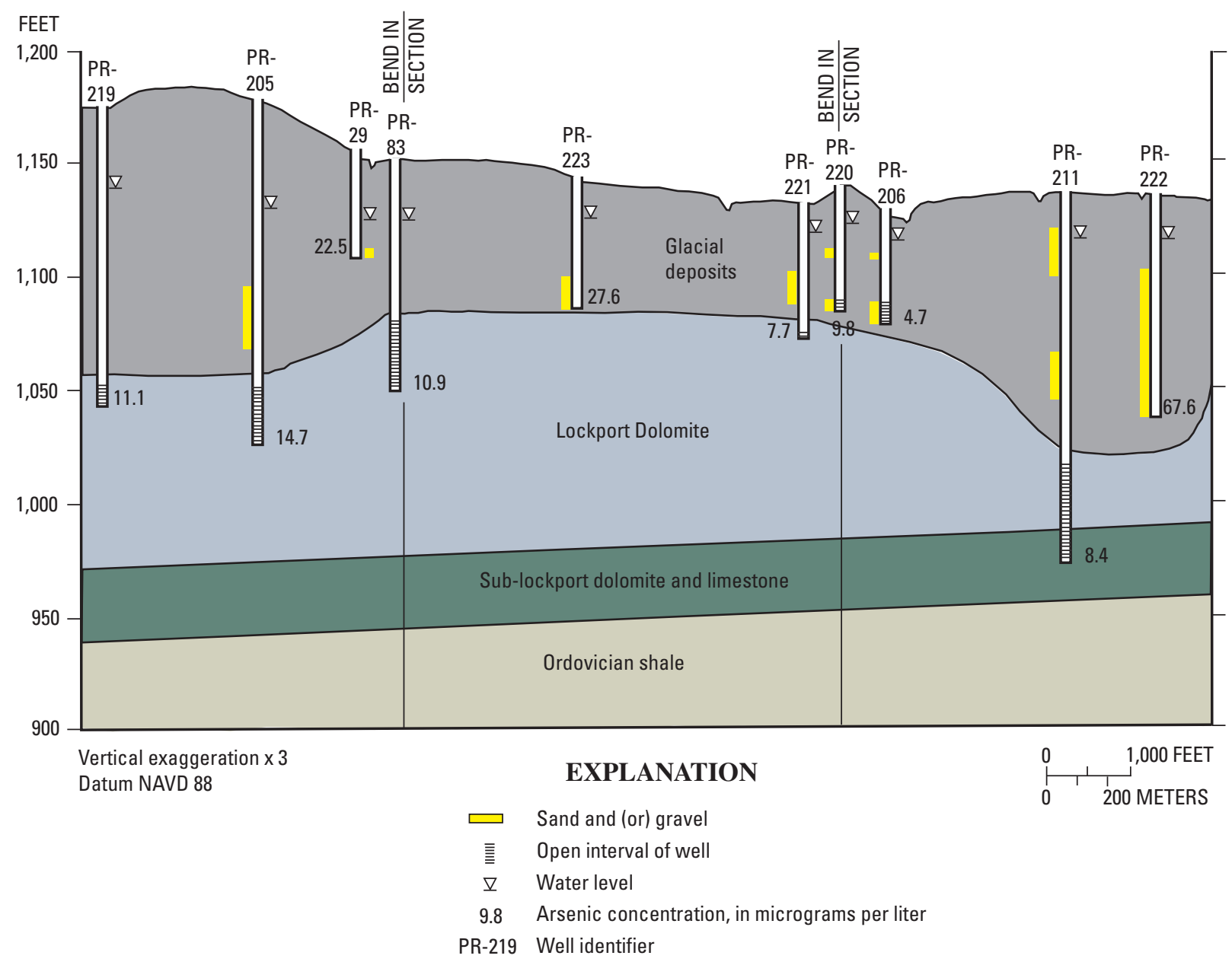

Figure 8. Arsenic concentrations in selected domestic wells in northern Preble County, Ohio. $A$, summary statistics, $B$, relation to well depth, and $C$, geologic section. (Location of geologic section is shown in fig. 7. Geologic nomenclature from table 1.) 


\section{Miami County Site}

This site in western Miami County is west of the confluence of Greenville Creek and the Stillwater River. Land-surface elevations are 895 to $1,010 \mathrm{ft}$, and depth to water is 13 to $91 \mathrm{ft}$ below land surface. In terms of the regional ground-water-flow system, this site is not clearly a regional recharge or discharge area (Eberts and George, 2000). A major buried valley cuts across the northwestern corner of the site. Glacial deposits are 100 to more than $200 \mathrm{ft}$ deep in buried valleys and 20 to $60 \mathrm{ft}$ deep overlying the bedrock uplands (areas not underlain by a buried valley). The lower part of the Lockport Dolomite subcrops in the uplands, and the subLockport formation and Ordovician shale subcrop along the buried valleys (Ohio Department of Natural Resources, Division of Geological Survey, 2004).

The site was of interest because elevated arsenic concentrations were detected in a publicsupply well that is $124 \mathrm{ft}$ deep and produces water from a buried-valley deposit. Between 1999 and 2003, seven samples from the public-supply well were analyzed for arsenic; the median was $23 \mu \mathrm{g} / \mathrm{L}$, and the range was 3.9 to $25.4 \mu \mathrm{g} / \mathrm{L}$ (Miami Conservancy District, 2004).

Within a 2-mi radius of the public-supply well, eight domestic wells that produce from carbonate bedrock were sampled for arsenic and related water-quality constituents. (At this site, it was not possible to sample buried valley deposits because most of domestic wells in this vicinity produce from carbonate bedrock.) The median arsenic concentration was $7.7 \mu \mathrm{g} / \mathrm{L}$, and the maximum was $13.7 \mu \mathrm{g} / \mathrm{L}$. One of the eight wells (12 percent) had an arsenic concentration greater than the MCL (fig. 9A). Well depths were 66 to $140 \mathrm{ft}$ (fig. 9B).

A geologic section that extends eastward from the major buried valley in the northwest corner of the site is shown in figure 9C. The maximum arsenic concentration $(13.7 \mu \mathrm{g} / \mathrm{L})$ was from a well on the flood plain of Harris Creek (MI-210). The well was relatively shallow, but the sample had concentrations of silica $(19.9 \mathrm{mg} / \mathrm{L})$ and fluoride $(1.1 \mathrm{mg} / \mathrm{L})$ characteristic of deeper, older water (Hem, 1985). 
$\boldsymbol{A}$

\begin{tabular}{ccccc}
\hline Aquifer & $\begin{array}{c}\text { Number } \\
\text { type }\end{array}$ & $\begin{array}{c}\text { of } \\
\text { samples }\end{array}$ & $\begin{array}{c}\text { Arsenic concentration, } \\
\text { micrograms per liter }\end{array}$ & \begin{tabular}{c} 
Percentage \\
of samples \\
exceeding 10 \\
\cline { 3 - 5 } micrograms \\
per liter
\end{tabular} \\
\hline Carbonate & 8 & 7.7 & 13.7 & 12 \\
\hline
\end{tabular}

$B$

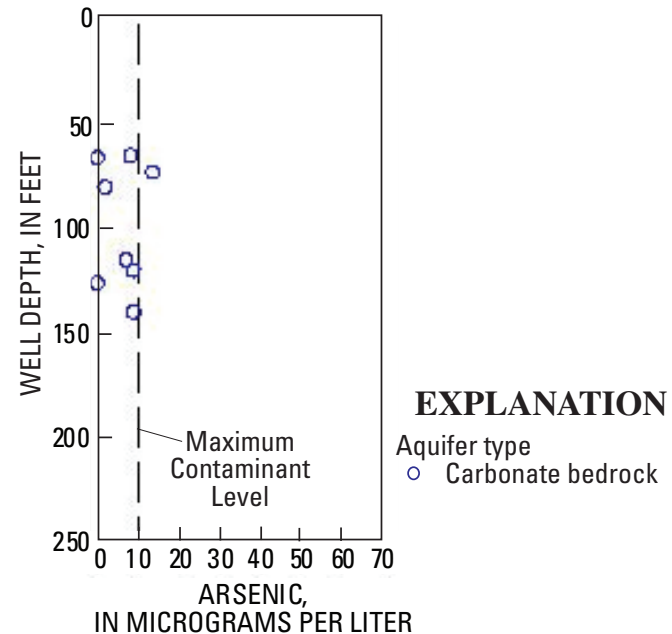

\section{C}

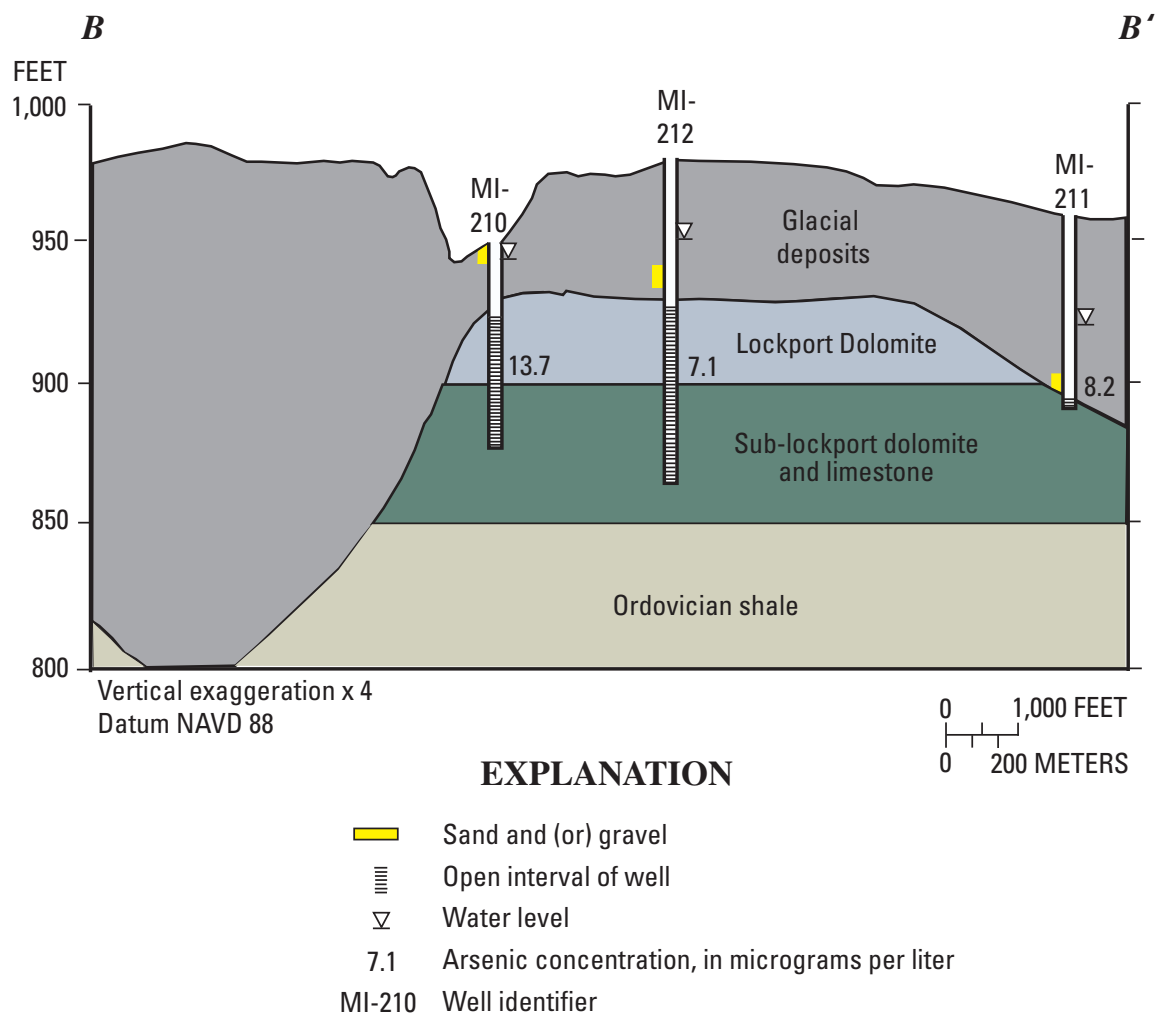

Figure 9. Arsenic concentrations in selected domestic wells in northwestern Miami County, Ohio. $A$, summary statistics, $B$, relation to well depth, and $C$, geologic section. (Location of geologic section is shown in fig. 7. Geologic nomenclature from table 1.) 


\section{Shelby County Site}

This site in southern Shelby County is near the confluence of the Great Miami River, Loramie Creek, and Turtle Creek. The area is one of regional ground-water discharge (Eberts and George, 2000). Land-surface elevations are 895 to $1,010 \mathrm{ft}$, and depth to water is 13 to $91 \mathrm{ft}$ below land surface. Compared to the other sites, this one covers a wider area, and the hydrogeology is more complex. A major buried valley and two tributary valleys are incised into bedrock (Ohio Department of Natural Resources, Division of Geological Survey, 2004). Glacial deposits are 8 to $134 \mathrm{ft}$ thick in upland areas and 225 to $350 \mathrm{ft}$ thick in the buried valleys. In upland areas, the upper part of the Lockport Dolomite subcrops, and the Salina formation subcrops in the extreme northeastern corner of the site. In and adjacent to buried valleys, the sub-Lockport and Ordovician shale subcrops.

The site was of interest because arsenic was detected in a small public-supply well that is $126 \mathrm{ft}$ deep and produces water from a buried valley. Between 1999 and 2003, six samples from the public-supply well were analyzed for arsenic. The median concentration was $17.8 \mu \mathrm{g} / \mathrm{L}$, and the range was 14.7 to $21 \mu \mathrm{g} / \mathrm{L}$ (Miami Conservancy District, 2004).

Within a 3.5-mi radius of the public-supply well, 28 domestic wells were chosen for sampling. Elevated arsenic concentrations were detected in at least one sample from each of the three aquifer types (fig. 10A). The wells sampled were 56 to $221 \mathrm{ft}$ deep (fig. 10B). Two geologic sections are shown for the Shelby County site. One of the sections focuses on the carbonate bedrock (fig. 10C), and the second focuses on a buried valley (fig. 10D). Figure $10 \mathrm{C}$ is a geologic section that runs from one of the tributary buried valleys to the northeastern corner of the site, where the base of the Salina formation subcrops. In general, lower arsenic concentrations were detected in shallower wells from the upper part of the Lockport Dolomite, and higher arsenic concentrations were in deeper wells that are open to both the Lockport and sub-Lockport formations.

A geologic section that traverses a buried valley from southwest to northeast is shown in figure 10D. In this section, the highest arsenic concentrations ( $27 \mu \mathrm{g} / \mathrm{L}$ and $18 \mu \mathrm{g} / \mathrm{L}$ ) were detected in medium-depth wells (123 and $132 \mathrm{ft}$ ) producing from gravel along the axis of the major buried valley (Ohio Department of Natural Resources, Division of Geological Survey, 2004). The two deepest wells in the buried valley (212 and $219 \mathrm{ft}$ deep) had low to moderate concentrations of arsenic (5.2 $\mu \mathrm{g} / \mathrm{L}$ and $1.9 \mu \mathrm{g} / \mathrm{L}$, respectively) (fig. 10D).

At the Shelby County site, the maximum arsenic concentration $(49.1 \mu \mathrm{g} / \mathrm{L})$ was in a sample from carbonate bedrock on the flank of a buried valley (not shown on geologic sections). In this area, buried-valley deposits overlie bedrock, and the open interval of well is directly overlain by $7 \mathrm{ft}$ of muddy gravel. The geochemistry of the sample from this well is more similar to samples from buried-valley deposits than those from carbonate bedrock. This sample will be referred to as the buried-valley/carbonate sample in later sections of this report. 
$\boldsymbol{A}$

\begin{tabular}{ccccc}
\hline \multirow{2}{*}{$\begin{array}{c}\text { Aquifer } \\
\text { type }\end{array}$} & $\begin{array}{c}\text { Number } \\
\text { of } \\
\text { samples }\end{array}$ & $\begin{array}{c}\text { Arsenic concentration, } \\
\text { micrograms per liter }\end{array}$ & $\begin{array}{c}\text { Percentage } \\
\text { of samples } \\
\text { exceeding 10 }\end{array}$ \\
\cline { 3 - 5 } & & Median & Maximum & $\begin{array}{c}\text { micrograms } \\
\text { per liter }\end{array}$ \\
\hline Carbonate & 12 & 10.2 & 49.1 & 50 \\
$\begin{array}{r}\text { Till with sand } \\
\text { and gravel }\end{array}$ & 3 & 6.4 & 13.3 & 33 \\
Buried valley & 13 & 4.0 & 27 & 23 \\
\hline
\end{tabular}

B

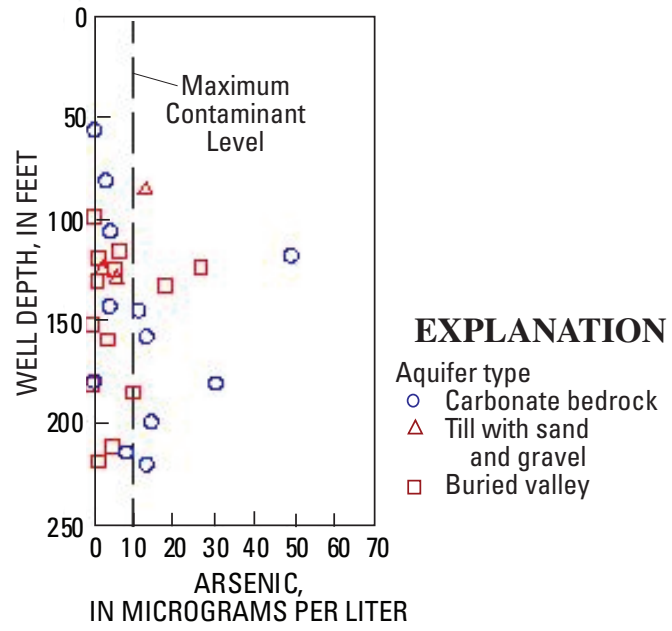

C

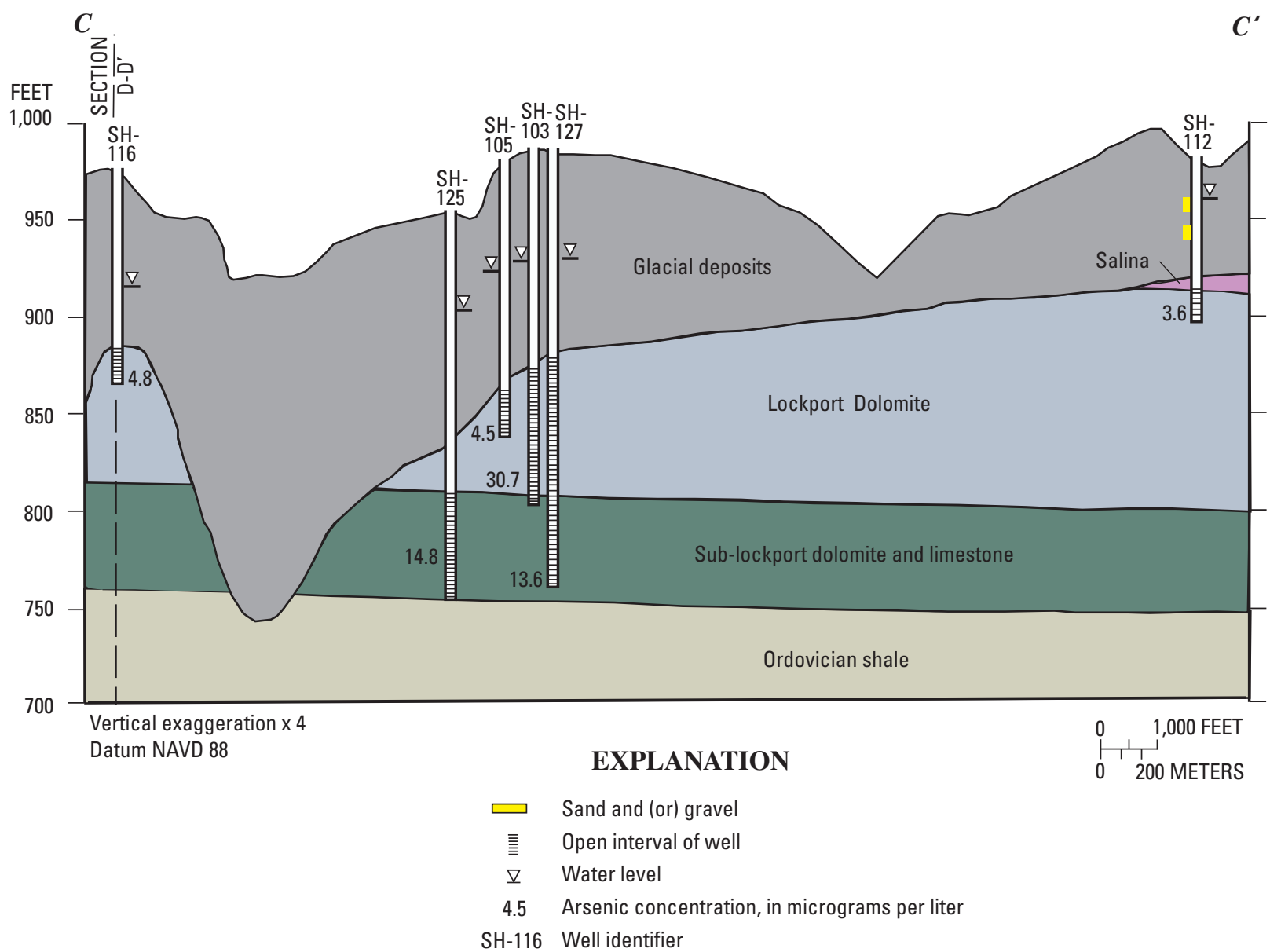

Figure 10. Arsenic concentrations in selected domestic wells in southern Shelby County, Ohio. $A$, summary statistics, $B$, relation to well depth, and $C$, geologic section. (Location of geologic section is shown in fig. 7. Geologic nomenclature from table 1.) 
$\boldsymbol{D}$

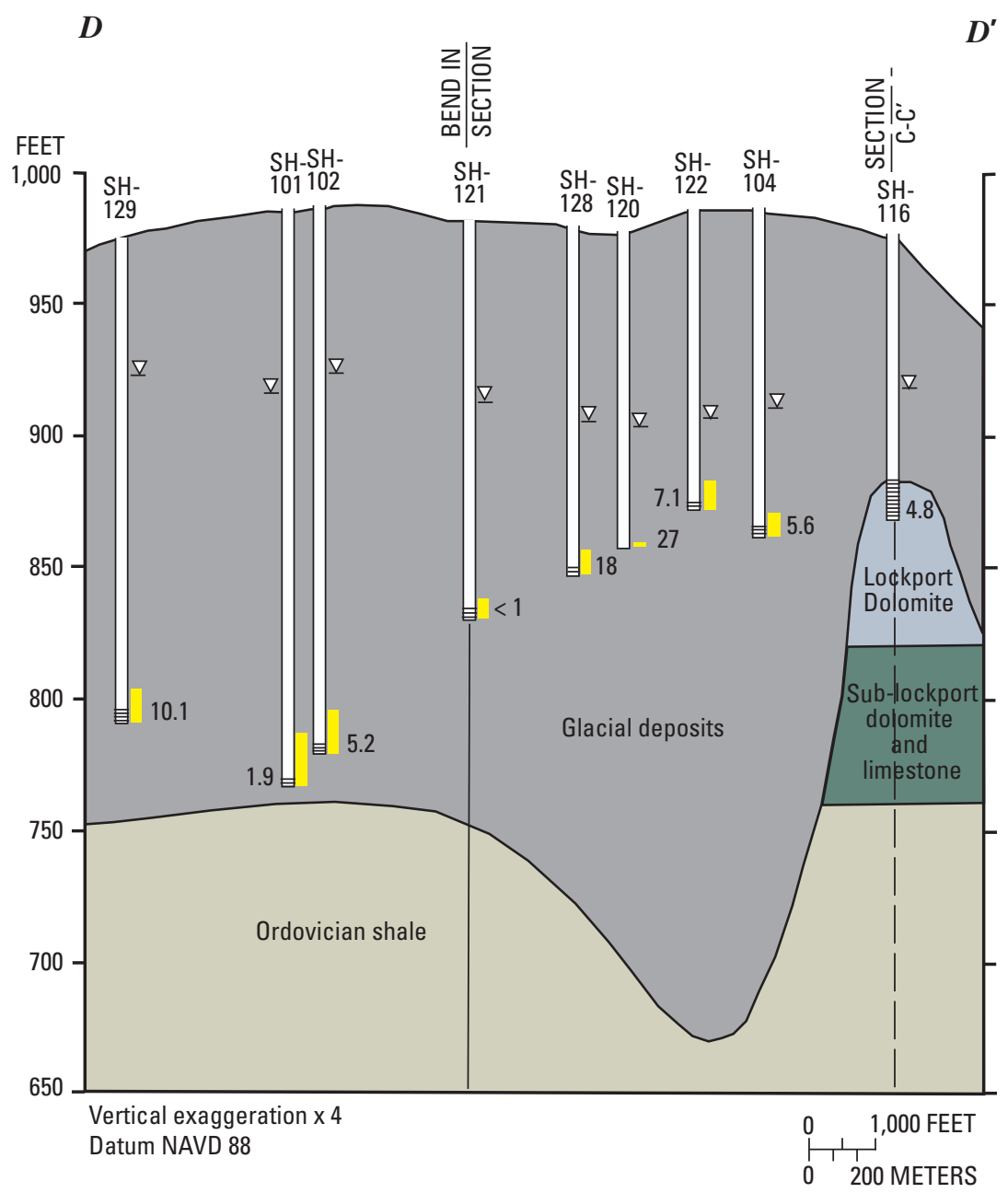

EXPLANATION

$\square \quad$ Sand and (or) gravel

豆 Open interval of well

$\square \quad$ Water level

5.2 Arsenic concentration, in micrograms per liter

SH-129 Well identifier

Figure 10. Arsenic concentrations in selected domestic wells in southern Shelby County, Ohio. $A$, summary statistics, $B$, relation to well depth, $C$ and $D$, geologic sections. (Location of geologic section is shown in fig. 7. Geologic nomenclature from table 1.)-Continued 


\section{Arsenic Concentrations in Relation to Selected Hydrogeologic and Geochemical Factors}

Factors related to arsenic occurrence can provide clues as to the source of arsenic and (or) the mechanism by which it is mobilized. Relations between arsenic and hydrogeologic or geochemical variables were investigated by means of graphical and statistical analyses. The nonparametric Kruskal-Wallis test was used to make comparisons among groups of data. Correlations between arsenic and other variables were tested using Spearman's rho, a nonparametric test for monotonic (rather than linear) correlation. For both tests, "significant" results are those with a significance level of 95 percent $(\mathrm{p}<0.05)$.

\section{Aquifer Type}

Arsenic concentrations in buried-valley deposits had a different data distribution than those in carbonate bedrock or till with sand and gravel (fig. 11). In buried-valley deposits, the data distribution was right-skewed; the median arsenic concentration was low $(4.6 \mu \mathrm{g} / \mathrm{L})$ and the maximum was very high $(67.6 \mu \mathrm{g} / \mathrm{L})$. Twenty-nine percent of samples had elevated arsenic concentrations ( $>10 \mu \mathrm{g} / \mathrm{L})$. In contrast, the data distribution was approximately normal for samples from till with sand and gravel. These samples had a lower maximum concentration $(27.6 \mu \mathrm{g} / \mathrm{L})$ but a higher median concentration $(11.4 \mu \mathrm{g} / \mathrm{L})$ and a higher percentage of samples with elevated arsenic concentrations (50 percent). For carbonate bedrock, arsenic concentrations are more similar to those of till with sand and gravel than to those of buried-valley deposits.
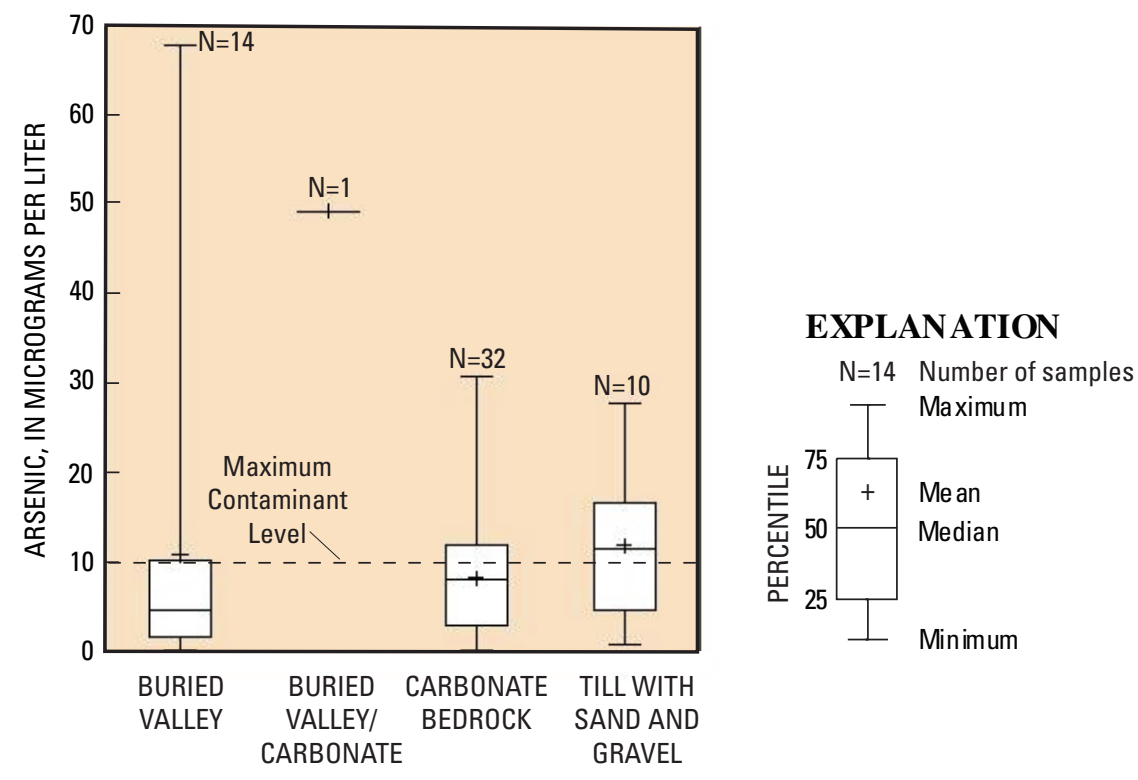

\begin{tabular}{lccccc}
\hline \multicolumn{1}{c}{$\begin{array}{c}\text { Aquifer } \\
\text { type }\end{array}$} & $\begin{array}{c}\text { Number } \\
\text { of }\end{array}$ & \multicolumn{2}{c}{$\begin{array}{c}\text { Arsenic concentration, } \\
\text { micrograms per liter }\end{array}$} & $\begin{array}{c}\text { Percentage } \\
\text { of samples } \\
\text { samples }\end{array}$ & $\begin{array}{c}\text { Maximum } \\
\text { exceeding 10 } \\
\text { micrograms } \\
\text { per liter }\end{array}$ \\
\hline Buried valley & 14 & 67.6 & 4.6 & 10.8 & 29 \\
Buried valley and carbonate & $\mathrm{a}_{1}$ & 49.1 & -- & -- & - \\
Carbonate & 32 & 30.7 & 8.0 & 8.2 & 34 \\
Till with sand and gravel & 10 & 27.6 & 11.4 & 11.8 & 50 \\
\hline
\end{tabular}

${ }^{\mathrm{a}}$ Insufficient data to calculate summary statistics.

Figure 11. Arsenic concentrations in three aquifer types, southwestern Ohio. 
Two other water-quality datasets from southwestern Ohio showed a similar contrast between arsenic concentrations in different aquifer types. Arsenic concentrations from 30 domestic wells in buried-valley deposits in the Little and Great Miami River Basins had a right-skewed distribution, with a median of less than $1 \mu \mathrm{g} / \mathrm{L}$ and a maximum of $53 \mu \mathrm{g} / \mathrm{L}$ (Thomas, 2003). In contrast, a dataset of 25 domestic wells in carbonate bedrock in southwestern Ohio (Preble, Miami, Darke, and Montgomery Counties) had an approximate normal distribution, with a median of $11 \mu \mathrm{g} / \mathrm{L}$ and a maximum of $29 \mu \mathrm{g} / \mathrm{L}$ (Dumouchelle, 1998).

\section{Depth}

The wells sampled were 42 to $221 \mathrm{ft}$ deep, and arsenic concentrations greater than the MCL were detected over the entire range of depths (fig. 12A). The highest arsenic concentrations $(67.6 \mu \mathrm{g} / \mathrm{L}$ and $49.1 \mu \mathrm{g} / \mathrm{L})$ were from intermediate-depth wells (93 and $118 \mathrm{ft}$ ). For the dataset as a whole $(\mathrm{N}=57)$, there was no significant correlation between arsenic concentrations and well depth or other depth-related variables, including (1) depth to the top of the open interval, (2) depth of the top of the open interval below the water level, (3) depth of water level, (4) thickness of till overlying the top of the open

\section{$\boldsymbol{A}$}

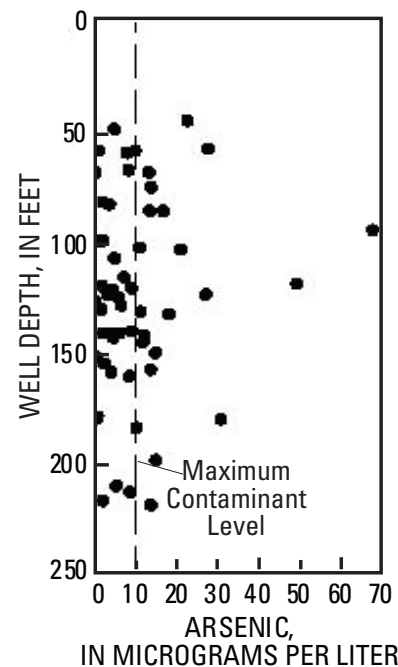

$\boldsymbol{B}$

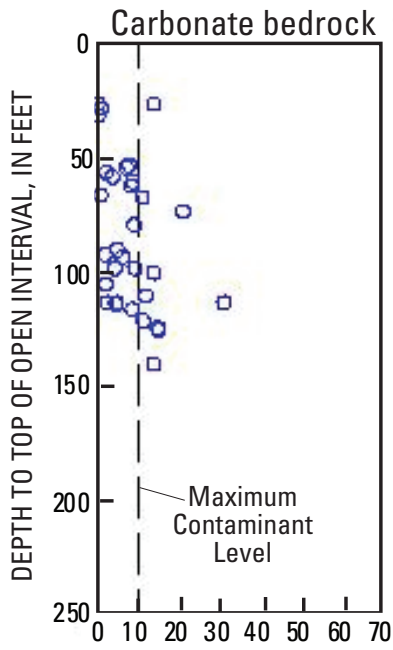

Till with sand and gravel

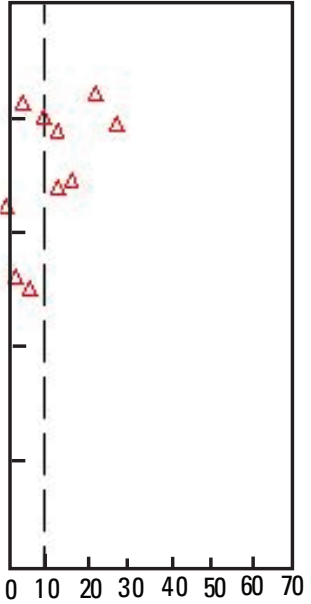

Buried valley

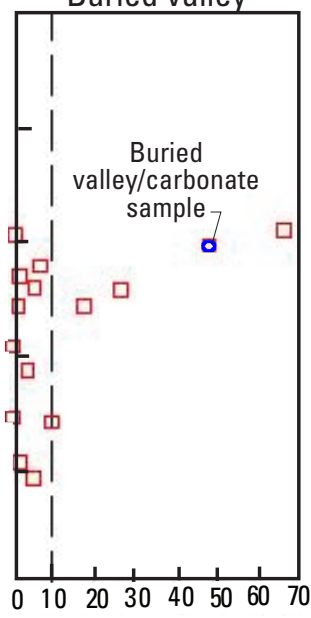

ARSENIC, IN MICROGRAMS PER LITER

Figure 12. Relation between arsenic concentrations and $(A)$ well depth for all samples and $(B)$ depth to the top of the open interval for three aquifer types, southwestern Ohio. 
interval, (5) length of the open interval, (6) elevation of the top of the open interval, (7) elevation of the bottom of the open interval, (8) elevation of the water level, or (9) elevation of the top of the open interval relative to the water level.

For buried-valley deposits and till with sand and gravel, arsenic concentrations appear to decrease with depth (fig. $12 B)$, but correlations between arsenic and depth-related variables were not statistically significant for these aquifer types.

In contrast, arsenic concentrations in carbonate bedrock were significantly correlated with well depth $(\mathrm{p}=0.0424$, rho=0.3609). Arsenic concentrations were higher in deeper wells. An even stronger correlation $(\mathrm{p}=0.0136$, $\mathrm{rho}=0.4384)$ was found between arsenic and the depth to the top of the open interval (fig 12B). Wells in carbonate bedrock had open intervals of 3 to $155 \mathrm{ft}$, so well depth was not always a good indication of the depth from which water was produced. For carbonate bedrock, arsenic was also significantly correlated with (1) depth of the top of the open interval below the water level and (2) total thickness of till overlying the top of the open interval.

It has been proposed that the thickness of glacial till that overlies the water-producing zone may be related to arsenic concentrations in ground water in northeastern Ohio (Matisoff and others, 1982) and southwestern Ohio (Bendula and Khoury, 1998). A thick layer of till at land surface could inhibit recharge of oxygenated water to the aquifer, thereby creating reducing conditions that are favorable for release of arsenic from iron oxides. This is consistent with observations from the carbonate bedrock in the study area; however, other depth-related variables were also correlated with arsenic.

\section{Bedrock Stratigraphy}

In the study area, the two major stratigraphic units are the Lockport Dolomite and the sub-Lockport formation (Schumacher, 1993; table 1). Chemical analyses of carbonate bedrock from Preble County indicate the concentration of pyrite (a potential source of arsenic) is greater in the sub-Lockport formation than in the Lockport Dolomite (Stout, 1941). In the current study, the correlation between arsenic and depth in carbonate bedrock could be the result of greater concentrations of pyrite in deeper parts of the carbonate bedrock. To investigate this hypothesis, the stratigraphic unit(s) in the open interval of each well were plotted in relation to depth of the top of the open interval (fig. 13). The results are ambiguous-elevated arsenic concentrations were detected in wells with intervals open to (1) the Lockport Dolomite and (2) both the Lockport and the sub-Lockport.

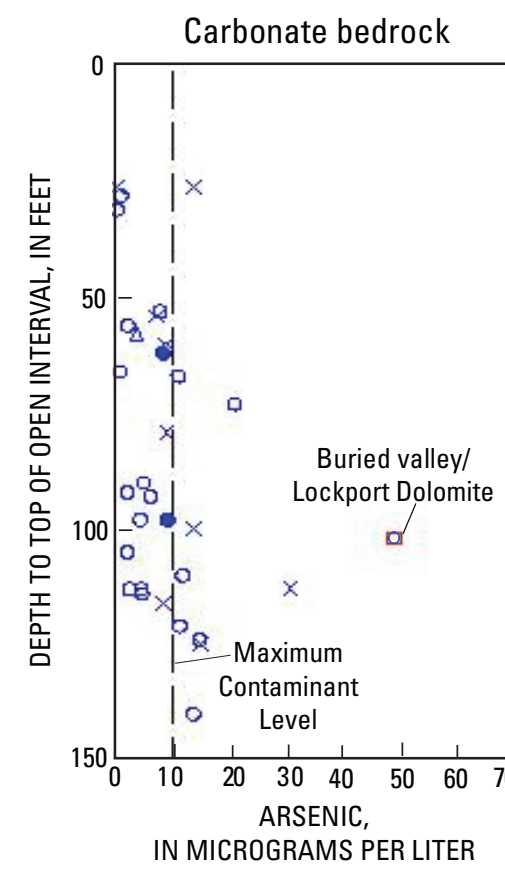

EXPLANATION

\author{
Stratigraphic unit(s) in open interval of well \\ in carbonate bedrock \\ $\triangle \quad$ Lockport Dolomite and Salina Group \\ - Lockport Dolomite \\ $x \quad$ Lockport Dolomite and sub-Lockport units \\ - Sub-Lockport unites
}

Figure 13. Arsenic concentrations in relation to the stratigraphic unit(s) included in the open interval of the well. 


\section{Redox Conditions}

Arsenic is a redox-sensitive constituent-its fate in ground water is partly controlled by reduction and oxidation (redox) processes. Redox reactions involve the transfer of electrons between compounds, and the reactions are commonly mediated by microbes.

Redox conditions of ground-water samples were estimated from concentrations of five redox-indicator species: dissolved oxygen, nitrate, manganese, iron, and sulfate. Significance levels for each of the redox-indicator species were developed by a National Water-Quality Assessment (NAWQA) Topical Study on the Transport of Anthropogenic and Natural Contaminants to Public-Supply Wells (U.S. Geological Survey, 2003, Method for redox classification (unpublished method for agency use)).

Samples classified as oxic or nitrate-reducing had oxygen and (or) nitrate concentrations greater than $0.5 \mathrm{mg} / \mathrm{L}$, manganese concentrations less than $50 \mu \mathrm{g} / \mathrm{L}$, and iron concentrations less than $100 \mu \mathrm{g} / \mathrm{L}$. Samples classified as iron-reducing or sulfate-reducing had oxygen and nitrate concentrations less than $0.5 \mathrm{mg} / \mathrm{L}$, iron concentrations greater than $100 \mu \mathrm{g} / \mathrm{L}$, and sulfate concentrations greater than or equal to $4 \mathrm{mg} / \mathrm{L}$. Samples classified as methanic had oxygen and nitrate concentrations less than $0.5 \mathrm{mg} / \mathrm{L}$, iron concentrations greater than $100 \mu \mathrm{g} / \mathrm{L}$, and sulfate concentrations less than $4 \mathrm{mg} / \mathrm{L}$.

Three of the 57 samples were oxic or nitrate-reducing, and all had arsenic concentrations less than $1 \mu \mathrm{g} / \mathrm{L}$. These three samples also had concentrations of nitrate $(>3 \mathrm{mg} / \mathrm{L})$ and (or) chloride ( $>20 \mathrm{mg} / \mathrm{L}$ ) that are presumably the result of human activities.

All samples with elevated arsenic concentrations were estimated to be iron reducing, sulfate reducing, or methanic.
In addition, all samples with elevated arsenic concentrations had iron concentrations greater than 1,000 $\mu \mathrm{g} / \mathrm{L}$ (fig. 14). This iron concentration is not unusual for the study area, but it is far greater than either the estimated lower threshold of iron-reducing conditions $(100 \mu \mathrm{g} / \mathrm{L})$ or the USEPA Secondary Maximum Contaminant Level for iron $(300 \mu \mathrm{g} / \mathrm{L})$, a non-enforceable standard based on esthetic criteria such as iron staining of household surfaces.

These observations - that all samples with elevated arsenic concentrations were iron reducing, sulfate-reducing, or methanic, and that all oxic or nitrate-reducing samples had very low concentrations of arsenic - are consistent with the hypothesis that arsenic was released from iron oxides under reducing conditions (by reductive dissolution or reductive desorption).

Even though arsenic and iron were significantly correlated, the relation between the two variables was not simple or straightforward. Of the samples with iron concentrations greater than 1,000 $\mu \mathrm{g} / \mathrm{L}, 42$ percent had elevated arsenic concentrations, and 58 percent did not. For example, the three samples with the highest iron concentrations $(9,800 \mu \mathrm{g} / \mathrm{L}$, $6,820 \mu \mathrm{g} / \mathrm{L}$, and $4,010 \mu \mathrm{g} / \mathrm{L}$ ) had varied arsenic concentrations $(49.1 \mu \mathrm{g} / \mathrm{L}, 1.9 \mu \mathrm{g} / \mathrm{L}$, and $5.6 \mu \mathrm{g} / \mathrm{L}$, respectively).

Low concentrations of arsenic in some of the reducing samples could be due to an absence of arsenic-bearing minerals in the aquifer materials. However, in some studies, arsenic in ground water is related more closely to redox conditions of the ground water than to concentrations of arsenic in the aquifer materials. In an investigation of arsenic in the Mahomet Valley aquifer in Illinois, low arsenic concentrations in ground water were attributed to sulfate-reducing conditions (Kirk and others, 2004). Under sulfate-reducing conditions, sulfate is reduced to sulfide, and iron sulfide minerals can precipitate. If

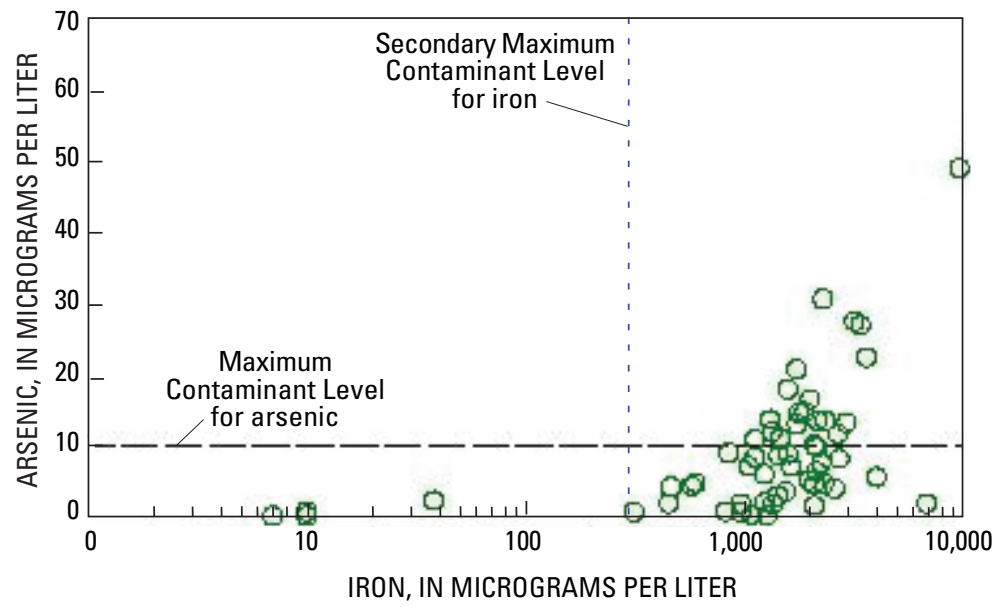

Figure 14. Relation between arsenic and iron concentrations in ground water. 
arsenic is present, it can precipitate along with the sulfide minerals, and thereby be removed from the ground water (Hem, 1985). In the current study, it is not known whether arsenic concentrations in ground water are principally controlled by redox conditions or by the concentration of arsenic within the aquifer materials.

Arsenic concentrations in relation to redox conditions in each aquifer type are shown in figure 15 .

For carbonate bedrock, arsenic concentrations increase with depth, and all samples with elevated arsenic concentrations were estimated to be iron reducing or sulfate reducing. The three oxic or nitrate reducing samples, from wells with shallow $(<31 \mathrm{ft}$ ) open intervals in carbonate bedrock, all had arsenic concentrations less than $1 \mu \mathrm{g} / \mathrm{L}$. An arsenic concentration of $13.7 \mu \mathrm{g} / \mathrm{L}$ was detected in a sample of iron- or sulfatereducing water from a similar depth. This sample was from a well in a flood plain (fig. 9), an area where deeper, older water can occur at shallow depths as a result of ground-water discharge to the stream.

At depths of less than $100 \mathrm{ft}$ deep, higher concentrations of arsenic and iron were detected in wells in till with sand and gravel than in carbonate bedrock (fig. 15).

Redox conditions in samples from buried-valley deposits were more reducing than from the other aquifer types. Half (7 of 14) of the buried-valley samples were estimated to be methanic. The other samples were iron or sulfate reducing (6 of 14) or mixed (1 of 14).

For the dataset as a whole, the two highest arsenic concentrations were detected in methanic samples from intermediate-depth wells. The maximum concentration $(67.6 \mu \mathrm{g} / \mathrm{L})$ was from a well in a shallow buried valley in Preble County, and the second highest $(49.1 \mu \mathrm{g} / \mathrm{L})$ was from Shelby County, in a well open to carbonate bedrock overlain by buried-valley deposits (referred to as the buried valley/carbonate sample).

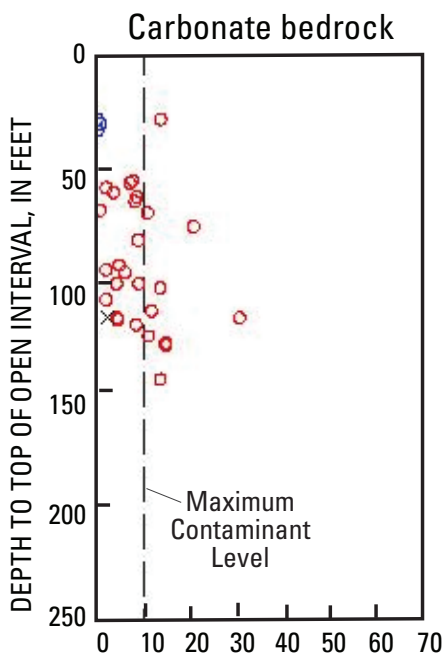

Till with sand and gravel

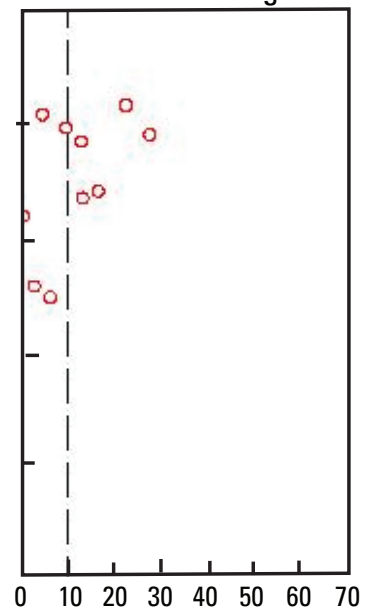

ARSENIC, IN MICROGRAMS PER LITER

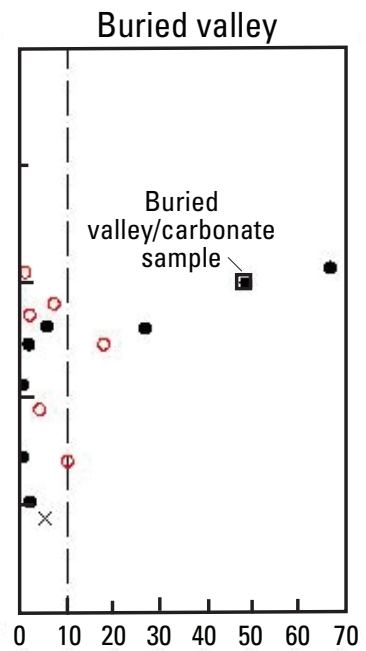

\section{EXPLANATION}

Estimated redox condition
Oxic or nitrate reducing

Figure 15. Relations between arsenic concentrations, estimated redox conditions, and depth to the top of the open interval for three aquifer types. 


\section{Correlation With Other Geochemical Constituents}

Correlations between arsenic and other chemical constituents were investigated using Spearman's rho. Constituents that were correlated with arsenic with at least a 95-percent confidence level are listed in table 2.

As discussed in the previous section, arsenic concentrations were directly related to iron concentrations (fig. 14). For buried-valley deposits, the lack of statistically significant correlation between arsenic and iron may be due to two factors: (1) all iron concentrations were relatively high $(>800 \mu \mathrm{g} / \mathrm{L})$, and (2) some samples with very high iron concentrations had low to moderate arsenic concentrations.

For carbonate bedrock and till with sand and gravel, arsenic was significantly correlated with alkalinity. As with the correlation between arsenic and iron, this correlation is consistent with the hypothesis that arsenic was released from iron oxides under reducing conditions. Reduction of iron oxides is coupled with microbial oxidation of organic carbon. Oxidation of organic carbon creates carbon dioxide, which is the principal source of the carbon dixoide species that produce alkalinity in ground water (Hem, 1985).

For carbonate bedrock, arsenic and molybdenum were significantly correlated (table 2). A similar strong relation between arsenic and molybdenum (and iron) was noted in studies of domestic wells in northern Alberta, Canada (Alberta Health and Wellness, 2000), and in Illinois (Warner, 2001). Molybdenum is an accessory element in many ores (Hem, 1985). In ground water, molybdenum occurs as an oxyanion, and so its mobility should be similar to that of arsenic (Smedley and Kinniburgh, 2002).

In carbonate bedrock, arsenic was also significantly correlated with strontium, fluoride, and silica (table 2). Similar correlations of arsenic with strontium, fluoride, and silica were noted for buried-valley deposits in the northern part of the Miami River Basin (Thomas, 2003). In northwestern Ohio, high concentrations of strontium and fluoride in ground water from glacial deposits were indicative of sulfide mineralization in the underlying carbonate bedrock (Deering and others, 1983). Goldhaber and others (2003) proposed that arsenic enrichment of aquifers of the midcontinent was related to secondary sulfide mineralization. In the current study, correlations of arsenic with strontium and fluoride could be an indirect link between arsenic in ground water and secondary sulfide minerals in carbonate bedrock.

For buried-valley deposits, concentrations of ammonia and dissolved organic carbon (DOC) were significantly higher than for the other aquifer types, as indicated by results of the Kruskal-Wallis test with a confidence level of 95 percent. Three of the four samples with elevated arsenic had elevated concentrations of ammonia (4.95 to $5.57 \mathrm{mg} / \mathrm{L})$ and DOC (4.1 to $5.7 \mathrm{mg} / \mathrm{L})$. The buried valley/carbonate sample also had elevated concentrations of the same two constituents (ammonia $=10.6 \mathrm{mg} / \mathrm{L}, \mathrm{DOC}=9 \mathrm{mg} / \mathrm{L}$ ). The correlations of arsenic with ammonia and DOC were not statistically significant (and therefore not shown in table 2), probably because some of the buried-valley samples with elevated DOC and ammonia had low arsenic concentrations.

Table 2. Chemical constituents with which arsenic is correlated in southwestern Ohio, based on results of Spearman's rho test.

$[\mathrm{N}$, number of samples; HS correlation is highly significant $(\mathrm{p}<0.0001$ and rho $>0.69)$; $\mathrm{S}$, correlation is significant $(\mathrm{p}<0.05$ and rho $>0.42)$; $-\mathrm{S}$, inverse correlation is significant $(\mathrm{p}<0.05)$; “-”, correlation is not significant $(\mathrm{p}>0.05]$

\begin{tabular}{lccc}
\hline \multicolumn{1}{c}{ Variable $^{\mathbf{a}}$} & $\begin{array}{c}\text { Carbonate bedrock } \\
\mathbf{N}=\mathbf{3 2}\end{array}$ & $\begin{array}{c}\text { Till with sand and gravel } \\
\mathbf{N}=\mathbf{1 0}\end{array}$ & $\begin{array}{c}\text { Buried valley } \\
\mathbf{N}=\mathbf{1 3}^{\mathbf{b}}\end{array}$ \\
\cline { 3 - 4 } Iron & $\mathrm{HS}$ & $\mathrm{S}$ & - \\
Alkalinity & $\mathrm{S}$ & $\mathrm{S}$ & - \\
Molybdenum & $\mathrm{HS}$ & - & - \\
Strontium & $\mathrm{S}$ & - & - \\
Silica & $\mathrm{HS}$ & - & - \\
Fluoride & $\mathrm{S}$ & - & - \\
Magnesium & $\mathrm{S}$ & $\mathrm{S}$ & $\mathrm{S}$ \\
Potassium & $\mathrm{S}$ & - & - \\
Manganese & - & $-\mathrm{S}$ & $-\mathrm{S}$ \\
Dissolved organic carbon & - & $-\mathrm{S}$ & - \\
\hline
\end{tabular}

\footnotetext{
a Relations between arsenic and the following constituents were not statistically significant: sodium, calcium, sulfate, $\mathrm{pH}$, chloride, phosphate, ammonia, nitrate, and dissolved oxygen.

b Sample PR-222 is not included in statistical tests because it was affected by a water softener.
} 
In another study, elevated arsenic concentrations in ground water from deltaic and fluvial deposits were linked to concentrations of solid-phase organic matter rather than arsenic (McArthur and others, 2001). Elevated concentrations of ammonia were the result of microbial degradation of peat or other organic matter.

\section{Future Work}

A followup study at the Preble County site was begun in 2004 by the USGS in cooperation with the Miami Conservancy District. The study includes additional water-quality sampling (including arsenic speciation), solid-phase analyses, and geochemical modeling for each of the three aquifer types. The goal is to answer some of the questions raised during the current study. For example, in each aquifer type, are arsenic concentrations in ground water more closely related to the arsenic content or to the organic carbon content of the aquifer materials? For carbonate bedrock, do arsenic concentrations increase with depth as a result of changes in redox conditions, or do deeper stratigraphic units have higher arsenic concentrations? Does the correlation of arsenic with molybdenum, strontium, and fluoride provide information as to the source of arsenic or its mechanism of mobilization? For buried-valley deposits, are elevated arsenic concentrations more closely related to the distribution of organic carbon within the buriedvalley deposits or to inflow from the bedrock-valley walls?

It is hoped that answers to these questions could contribute to understanding of which parts of the ground-water system are most (and least) likely to have elevated concentrations of arsenic. This information might allow homeowners and water suppliers to avoid drilling wells in areas susceptible to arsenic contamination. If avoidance is not possible, monitoring or educational activities could be focused on the most susceptible areas.

\section{Summary}

During 2002 and 2003, the USGS, in cooperation with the Miami Conservancy District, measured concentrations of arsenic and related water-quality constituents in 57 domestic wells in southwestern Ohio. The median arsenic concentration was $7.1 \mu \mathrm{g} / \mathrm{L}$, and the maximum was $67.6 \mu \mathrm{g} / \mathrm{L}$. Thirty-seven percent of samples had arsenic concentrations greater than 10 $\mu \mathrm{g} / \mathrm{L}$, the USEPA Maximum Contaminant Level (MCL). The percentage of samples exceeding the MCL in this study is not necessarily representative of southwestern Ohio because the sites chosen for sampling were known to have elevated concentrations based on previous water-quality studies. However, observations about arsenic concentrations in relation to aquifer type, depth, redox conditions, and other geochemical constituents are probably applicable to larger areas.
The 57 ground-water samples were from three aquifer types - carbonate bedrock, glacial till with sand and gravel, and glacial buried-valley deposits. Elevated arsenic concentrations were detected in each aquifer type, and over a wide range of depths (42 to $221 \mathrm{ft}$ ).

One factor in common among all samples with elevated arsenic concentrations was that the iron concentrations were greater than 1,000 $\mu \mathrm{g} / \mathrm{L}$. Redox conditions of these samples were estimated to be iron reducing, sulfate reducing, or methanic. Relations of arsenic with iron and alkalinity are consistent with the hypothesis that arsenic was released from iron oxides under reducing conditions (by dissolution or desorption). Even though elevated arsenic concentrations were from reducing ground water, not all reducing ground water had elevated arsenic concentrations; 42 percent of the reduced ground-water samples had elevated arsenic concentrations and 58 percent did not.

Comparisons among the three aquifer types revealed some differences in arsenic occurrence. For carbonate bedrock, the median arsenic concentration was $8.0 \mu \mathrm{g} / \mathrm{L}$, and the maximum concentration was $30.7 \mu \mathrm{g} / \mathrm{L}$. Elevated arsenic concentrations were detected in iron- or sulfate-reducing samples. Arsenic concentrations were significantly correlated with well depth and other depth-related variables. In addition, arsenic was correlated with molybdenum, strontium, fluoride, and silica.

For till with sand and gravel, the median arsenic concentration was $11.4 \mu \mathrm{g} / \mathrm{L}$, and the maximum concentration was $27.6 \mu \mathrm{g} / \mathrm{L}$. Half of the samples had arsenic concentrations that exceeded the MCL. Samples from shallow wells ( $<100 \mathrm{ft})$ had higher concentrations of arsenic and iron than those from carbonate bedrock.

For buried-valley deposits, most arsenic concentrations were low (the median was $4.6 \mu \mathrm{g} / \mathrm{L}$ ), but a few were very high (the maximum was $67.6 \mu \mathrm{g} / \mathrm{L}$ ). There was no significant correlation between arsenic concentration and well depth; the highest arsenic concentrations were from intermediate-depth wells. Compared to other aquifer types, samples from buriedvalley deposits were more reducing; half of the samples were estimated to be methanic. Most of the buried-valley samples with elevated arsenic concentrations also had elevated concentrations of dissolved organic carbon and ammonia.

A followup study that includes solid-phase analyses and geochemical modeling was begun in 2004 by the USGS in cooperation with the Miami Conservancy District. It is hoped that results of the current and future studies will contribute to understanding of which parts of the ground-water system are most (and least) likely to have elevated concentrations of arsenic. 


\section{References Cited}

Alberta Health and Wellness, 2000, Arsenic in groundwater from domestic wells in three areas of Northern Alberta: Health Surveillance Report, 40 p.

Appelo, C.A.J., and Postma, D.,1999, Geochemistry, groundwater and pollution: Rotterdam, A.A. Balkema, 536 p.

Bendula, Rich, 1996, Arsenic in bedrock wells: Ohio Environmental Protection Agency Division of Drinking and Ground Waters, unpublished report, $6 \mathrm{p}$.

Bendula, Rich, and Khourey, Chris, 1998, Arsenic in bedrock wells: Ohio Environmental Protection Agency Division of Drinking and Ground Waters, Drinking and Ground Water News, v. 4, issue 1.

Berg, Michael; Hong Con Tran; Thi Chuyen Nguyen; Hung Viet Pham; Schertenleib, Roland; and Giger, Walter, 2001, Arsenic contamination of groundwater and drinking water in Vietnam-A human health threat: Environmental Science \& Technology, v. 35, no. 13, p. 2621-2626.

Blackman, M.J., 1970, A detailed study of the Pleistocene history of a portion of Preble County, Ohio: Oxford, Ohio, Miami University, Master's Thesis, 136 p.

Botoman, George, 1975, Precambrian and Paleozoic stratigraphy and potential mineral deposits along the Cincinnati Arch of Ohio: Columbus, Ohio, The Ohio State University, Master's Thesis, $137 \mathrm{p}$.

Botoman, George, and Stieglitz, R.D., 1978, The occurrence of sulfide and associated minerals in Ohio: Ohio Division of Geologic Survey Report of Investigations 104, 11 p.

Breit, G.N.; Whitney, J.; Foster, A.L.; Welch, A.H.; Yount, J.; Sanzolone, R.; Islam, Md. K.; Islam, Md. S.; Islam, Md. M.; Sutton, S.; and Newville, M., 2001, Preliminary evaluation of arsenic cycling in the sediments of Bangladesh, in Proceedings of the 2001 U.S. Geological Survey Workshop on Arsenic in the Environment, Denver, Colo., Feb. 21-22, 2001, accessed July 2001 at http://wwwbrr.cr.usgs.gov/Arsenic/finalabstracts.html

Brenton, R.W., and Arnett, T.L., 1993, Methods of analysis by the U.S. Geological Survey National Water-Quality Laboratory-Determination of dissolved organic carbon by UVpromoted persulfate oxidation and infrared spectrometry: U.S. Geological Survey Open-File Report 92-480, 12 p.

Casey, G.D., 1992, Hydrogeology of basal confining unit of the carbonate aquifer system in the Midwestern Basins and Arches region of Indiana, Ohio, Michigan, and Illinois: U.S. Geological Survey Open-File Report 92-489, 2 sheets.
Deering, M.F., Mohr, E.T., Sypniewski, B.F., and Carlson, E.H., 1983, Regional hydrogeochemical patterns in ground water of northwestern Ohio and their relation to Mississippi-Valley-type mineral occurrences: Journal of Geochemical Exploration, v. 19, p. 225-241.

Dumouchelle, D.H., 1998, Selected ground-water quality data of the Lockport Dolomite in Darke, Miami, Montgomery, and Preble Counties, Ohio: U.S. Geological Survey OpenFile Report 98-655, 13 p.

Eberts, S.M., and George, L.L., 2000, Regional ground-water flow and geochemistry in the Midwestern Basins and Arches Aquifer System in parts of Indiana, Ohio, Michigan, and Illinois: U.S. Geological Survey Professional Paper 1423-C, 103 p.

Fenneman, N.M., and Johnson, D.W., 1946, Physical divisions of the United States: U.S. Geological Survey, scale $1: 7,000,000$.

Fishman, M.J., ed., 1993, Methods of analysis by the U.S. Geological Survey National Water-Quality LaboratoryDetermination of inorganic and organic constituents in water and fluvial sediments: U.S. Geological Survey OpenFile Report 93-125, 217 p.

Garbarino, J.R., 1999, Methods of analysis by the U.S. Geological Survey National Water-Quality Laboratory-Determination of dissolved arsenic, boron, lithium, selenium, strontium, thallium, and vanadium using inductively coupled plasma-mass spectrometry: U.S. Geological Survey Open-File Report 99-093, 31 p.

Gerrard, T.A., 1959, A petrographic study of the Dayton Formation (Niagaran Series), Harrison and Twin Townships, Preble County, Ohio: Oxford, Ohio, Miami University, Master's Thesis, $77 \mathrm{p}$.

Goldhaber, M.B., Lee, R.C., Hatch, J.R., Pashin, J.C., and Treworgy, J., 2003, Role of large-scale fluid-flow in subsurface arsenic enrichment, in Welch, A.H., and Stollenwerk, K.G., eds., Arsenic in ground water-Occurrence and geochemistry: Boston, Kluwer Academic Publishers, chap. 5, p. 127-164.

Hach Company, 1993, Procedures manual_-DR/2000 spectrophotometer: Loveland, Colo. [variously paginated].

Hem, J.D., 1985, Study and interpretation of the chemical characteristics of natural water (3d ed.): U.S. Geological Survey Water-Supply Paper 2254, 263 p.

Hopkins, R.M., Jr., 1954, A petrographic study of the Brassfield Limestone in southwestern Ohio: Columbus, Ohio, The Ohio State University, Master's Thesis, 91 p. 
Kirk, M.F.; Holm, T.R.; Park, Jungho; Jin, Qusheng; Sanford, R.A.; Fouke, B.W.; and Bethke, C.M., 2004, Bacterial sulfate reduction limits natural arsenic contamination in groundwater: Geology, v. 32, no. 11, p. 953-956.

Kolker, Allan, Haack, S.K., Cannon, W.F., Westjohn, D.B., M.-J. Kim, Nriagu, Jerome, and Woodruff, L.G., 2003, Arsenic in southeastern Michigan in Welch, A.H., and Stollenwerk, K.G., eds., Arsenic in ground water-Occurrence and geochemistry: Boston, Kluwer Academic Publishers, chap. 10, p. 281-294.

Korte, N., 1991, Naturally occurring arsenic in groundwaters of the Midwestern United States: Environmental Geology and Water Science, v. 18, no. 2, 137-141.

Kostelnick, R.J., 1983, Ground-water resources of Shelby County: Ohio Department of Natural Resources, scale $1: 62,500$.

Matisoff, G., Khourey, K.J., Hall, J.F., and Strain, W.H., 1982, The nature and source of arsenic in northeastern Ohio ground water: Ground Water, v. 20, no. 4, p. 101-348.

McCarthur, J.M., Ravenscroft, R., Safiulla, S., and Thirwall, M.F., 2001, Arsenic in groundwater-Testing pollution mechanisms for sedimentary aquifers in Bangladesh: Water Resources Research, v. 37, no. 1, p. 109-117.

Miami Conservancy District, 2001, State of the aquifer, Lower Great Miami Sub-basin-January 2001: Dayton, Ohio, 45 p.

Miami Conservancy District, 2004, Water resource monitoring, groundwater quality data, accessed April 1, 2003, at http://www.miamiconservancy.org/Water_Resource_Monitoring

National Research Council, 1999, Arsenic in drinking water: Washington, D.C., National Academy Press, 273 p.

Norris, S.E., and Fidler, R.E., 1973, Availability of water from limestone and dolomite aquifers in southwestern Ohio and the relation of water quality to the regional flow system: U.S. Geological Survey Water-Resources Investigations 17-73, $42 \mathrm{p}$.

Ohio Department of Natural Resources, Division of Geological Survey, 2004, Shaded bedrock topography map of Ohio (digital coverage): BG-3, version 1.1.

Ohio Environmental Protection Agency, 2000, 2000 305(B) Report, Ohio's ground water quality: Division of Drinking and Ground Waters, p. 33-37.

Ohio Environmental Protection Agency, 2002, 2002 305(B) Report, Ohio's ground water quality: Division of Drinking and Ground Waters, p. 67-75.
Petty, Rebecca, 2000a, Treatment of arsenic in private ground water supplies, Jackson County, Ohio [abs.], in Water Management of Ohio Fall Conference, Columbus, Ohio, November 13-14, 2000.

Petty, Rebecca, 2000b, Investigation of arsenic in private water systems in Jackson, Vinton, and Perry Counties, Ohio [abs.], in 45th Annual Midwest Ground Water Conference, Columbus, Ohio: p. 64.

Ryker, S.J., 2003, Arsenic in ground water used for drinking water in the United States in Welch, A.H., and Stollenwerk, K.G., eds., Arsenic in ground water-Occurrence and geochemistry: Boston, Kluwer Academic Publishers, chap. 6, p. 165-178.

Rowe, G.L., Jr., Reutter, D.C., Runkle, D.L., Hambrook, J.A., Janosy, S.D., and Hwang, L.H., 2004, Water quality in the Great and Little Miami River Basins, Ohio and Indiana1999-2001: U.S. Geological Survey Circular 1229, 40 p.

Schlottman, J.L., 2001, Naturally occurring arsenic in the Central Oklahoma aquifer, in Proceedings of the 2001 U.S. Geological Survey Workshop on Arsenic in the Environment, Denver, Colo., Feb. 21-22, 2001, accessed July 2001, at http://wwwbrr.cr.usgs.gov/Arsenic/finalabstracts.html

Schmidt, J.J., 1984, Ground-water resources of Miami County: Ohio Department of Natural Resources, scale 1:62,500.

Schreiber, M.E., Gotkowitz, M.B., Simo, J.A., and Freiberg, P.G., 2003, Mechanisms of arsenic release to ground water from naturally occurring sources, eastern Wisconsin in Welch, A.H., and Stollenwerk, K.G., eds., Arsenic in ground water-Occurrence and geochemistry: Boston, Kluwer Academic Publishers, chap. 9, p. 259-280.

Schruben, P.G., Arndt, R.E., Bawiec, W.J., and Ambroziak, R.A., 1997, Geology of the conterminous United States at 1:2,500,000 scale-A digital representation of the 1974 P.B. King and H.M. Beikman map: U.S. Geological Survey Digital Data Series DDS-11, Release 2.

Schumacher, G.A., 1993, Regional bedrock geology of the Ohio portion of the Piqua, Ohio-Indiana 30 x 60 minute quadrangle: Ohio Department of Natural Resources, Division of Geological Survey, Map 6, scale 1:100,000.

Shindel, H.L., Mangus, J.P., and Frum, S.R., 2003, Water resources data, Ohio, water year 2002: U.S. Geological Survey Water-Data Report OH-02-2, accessed September 1, 2003, at http://pubs.water.usgs.gov/WDR-OH-O2/WDR$O H-A R-02-2 . p d f$

Shindel, H.L., Mangus, J.P., and Frum, S.R., 2004, Water resources data, Ohio, water year 2003: U.S. Geological Survey Water-Data Report OH-03-2, accessed June 1, 2004, at http://pubs.water.usgs.gov/WDR-OH-03/WDR-OH-AR-032.pdf 
Slattery, M., Kenah, C., Slattery, L., and Musser, K., 2000, Occurrence and release of groundwater arsenic in public water supply wells in Ohio [abs.], in 45th Annual Midwest Ground Water Conference, Columbus, Ohio: p. 63.

Smedley, P.L., and Kinniburgh, 2002, A review of the source, behaviour and distribution of arsenic in natural waters: Applied Geochemistry, v. 17, p. 517-568.

Soller, D.R., and Packard, P.H., 1998, Digital representation of a map showing the thickness and character of Quaternary sediments in the glaciated United States east of the Rocky Mountains: U.S. Geological Survey Digital Data Series DDS-38.

Stout, Wilber, 1941, Dolomites and limestones of Western Ohio: Geological Survey of Ohio, Fourth Series, Bulletin 42, $468 \mathrm{p}$.

Strobel, M.L., 1993, Hydraulic properties of three types of glacial deposits in Ohio: U.S. Geological Survey WaterResources Investigations Report 92-4135, 42 p.

Thomas, M.A., 2003, Arsenic in Midwestern glacial deposits-Occurrence and relation to selected hydrogeologic and geochemical factors: U.S. Geological Survey WaterResources Investigations Report 03-4228, 36 p.

U.S. Environmental Protection Agency, 2001, EPA to implement $10 \mathrm{ppb}$ standard for arsenic in drinking water: Office of Water Fact Sheet, EPA 815-F-01-010, October 2000, accessed November 9, 2001, at http://www.epa.gov/ safewater/ars/ars-oct-factsheet.html

U.S. Geological Survey, 1999, U.S. Geological Survey’s Mineral Resources Program activities in the Upper Midwest: USGS information handout, $4 \mathrm{p}$.

Walker, A.C., 1986, Ground-water resources of Preble County: Ohio Department of Natural Resources, scale 1:62,500.

Warner, K.L., 2001, Arsenic in glacial drift aquifers and the implications for drinking water-Lower Illinois River Basin: Ground Water, v. 39, no. 3, p. 333-347.

Welch, A.H., Lico, M.S., and Hughes, J.L., 1988, Arsenic in ground water of the Western United States: Ground Water, v. 26 , no. 3 , p. 333-347.

Welch, A.H., Westjohn, D.B., Helsel, D.R., and Wanty, R.B., 2000, Arsenic in ground water of the United States-Occurrence and geochemistry: Ground Water, v. 38, no. 4, p. 589-604.

Wilde, F.D., Radtke, D.B., Gibs, Jacob, and Iwatsubo, R.T., eds., 1999, National field manual for the collection of waterquality data: U.S. Geological Survey Techniques of WaterResouces Investigations, book 9, chaps. A4, A5, and A6.
Zobrist, Juerg, 2000, Mobilization of arsenite by dissimilatory reduction of adsorbed arsenate: Environmental Science \& Technology, v. 34, no. 22, p. 4747-4753. 


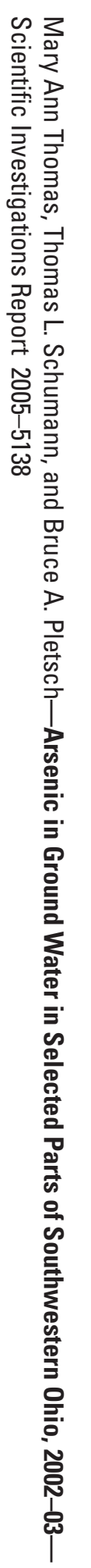

